\title{
$\ldots 1471$
}

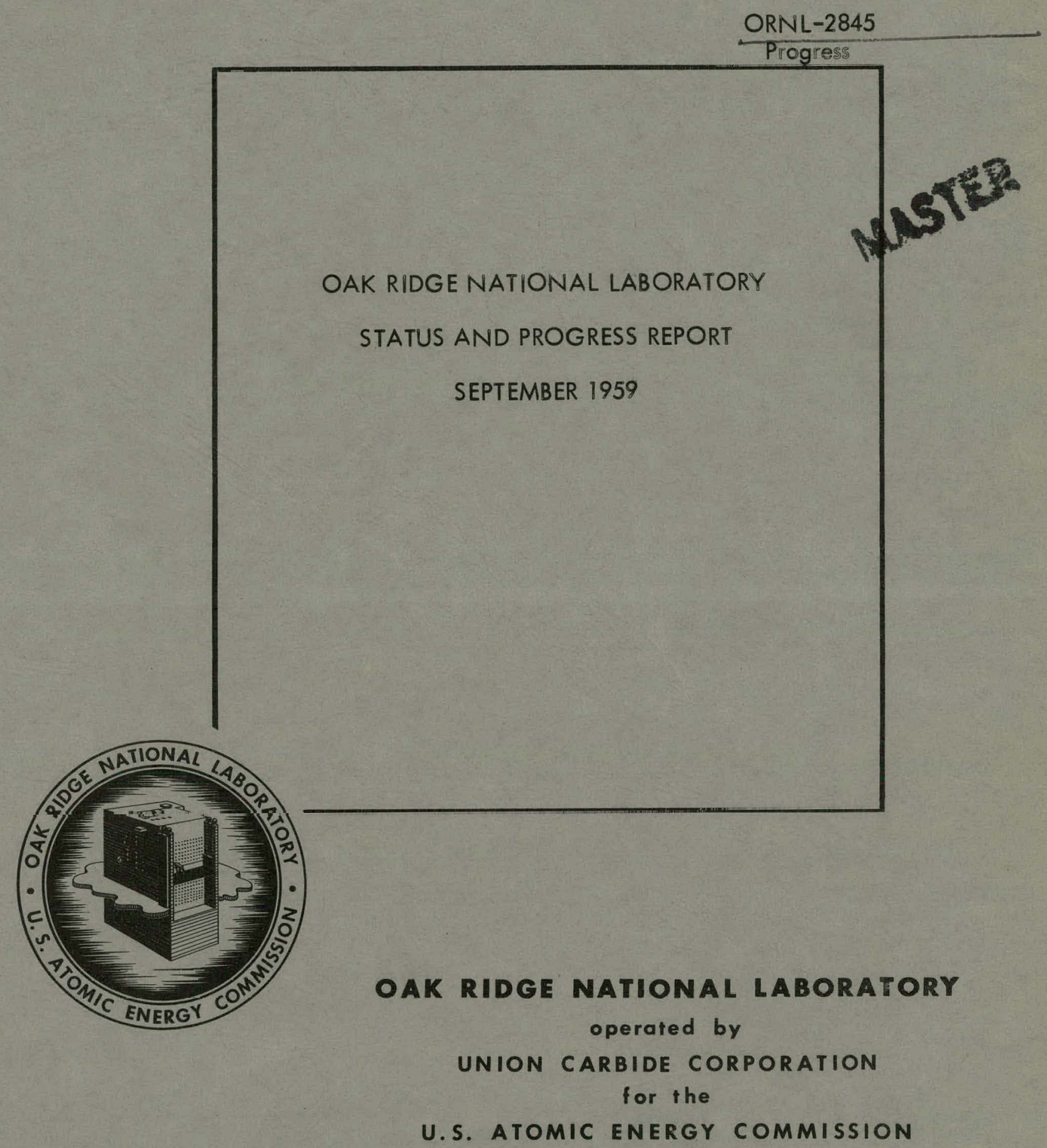

Downgrade to Unclassified After October 6, 1960 


\section{DISCLAIMER}

This report was prepared as an account of work sponsored by an agency of the United States Government. Neither the United States Government nor any agency Thereof, nor any of their employees, makes any warranty, express or implied, or assumes any legal liability or responsibility for the accuracy, completeness, or usefulness of any information, apparatus, product, or process disclosed, or represents that its use would not infringe privately owned rights. Reference herein to any specific commercial product, process, or service by trade name, trademark, manufacturer, or otherwise does not necessarily constitute or imply its endorsement, recommendation, or favoring by the United States Government or any agency thereof. The views and opinions of authors expressed herein do not necessarily state or reflect those of the United States Government or any agency thereof. 


\section{DISCLAIMER}

Portions of this document may be illegible in electronic image products. Images are produced from the best available original document. 


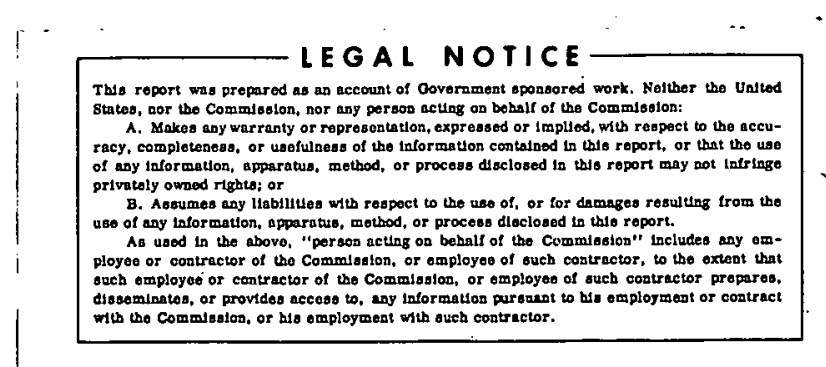

Contract No. W-7405-eng-26

OAK RIDGE INATIONAL LABORATORY

STATUS AIND PROGRESS REPORT

SEPTEMBER 1959

\section{OCT $6 \quad 1959$}

OAK RIDGE NATIONAL LABORATORY Oak Ridge, Tennessee operated by

UNION CARBIDE CORPORATION

for the

U.S. ATONIC ENERRY COMMISSION 


\section{THIS PAGE WAS INTENTIONALLY LEFT BLANK}


PROGRAM 2000 - SPECIAL NUCLEAR MATERIALS.............. I

Power Reactor Fuel Reprocessing Pilot Plant....... I I

PROGRAM 4000 - REACTOR DEVELOPMENT................ I

GAS-COOLED REACTOR PROGRAM................. I

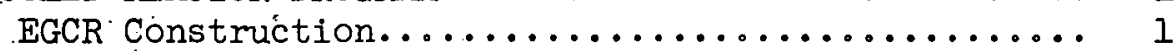

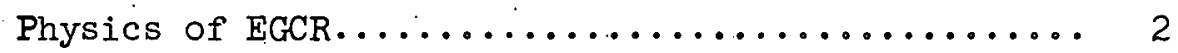

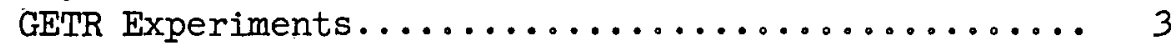

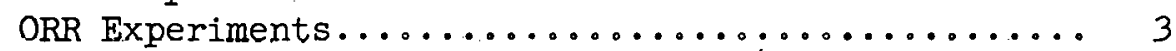

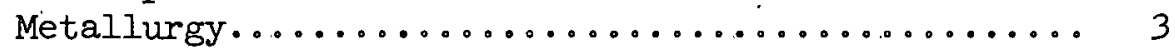

Heat Transfer Experiments.................. 3

THERMAL-BREEDER REACTOR PROGRAM............... 4

Homogeneous Reactor Program.................. 4

Homogeneous Reactor Test.................. 4

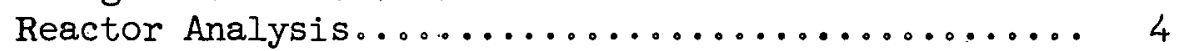

Homogeneous Reactor Instrumentation............ 4

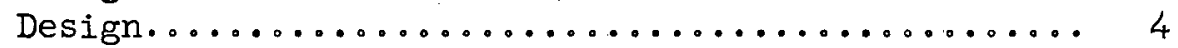

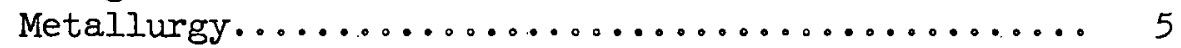

Laboratory. Corrosion Studies............... 5

Dynamic Solution Corrosion Tests.............. 6

In-Pile Solution Corrosion Loops............... 6

Molten-Salt Reactor Program................. 7

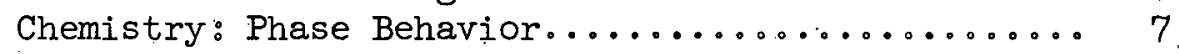

Chemistry: Graphite Compatibility............ 7

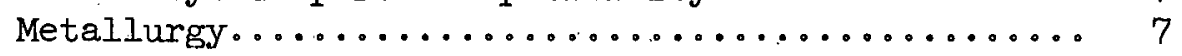

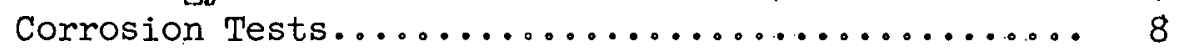

Graphite Systems...................... 8

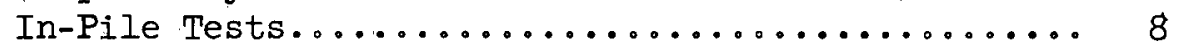

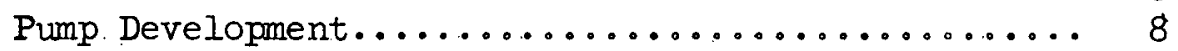

Remote Maintenance Demonstration.............. 9

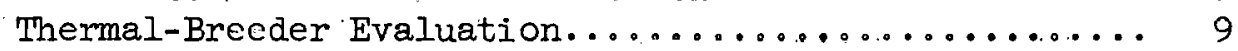

Graphite-Moderator, Gas-Cooled Breeder Reactor..... 9

Protactinium Poison Limitation in One-Region

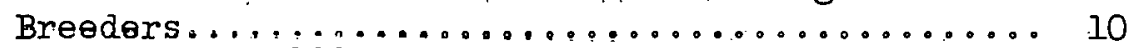

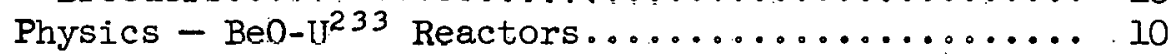

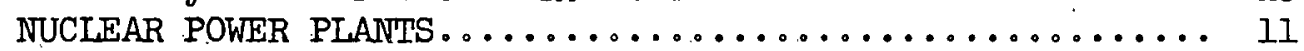

Small-Size Nuclear Power Plants................. 11

HIGH FLUX ISOTOPE REACTOR. .................... 11

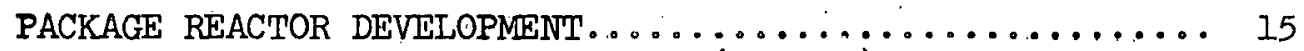

Army Pàckage Pówer Reactor $(A P P R-1) \ldots \ldots \ldots \ldots \ldots$

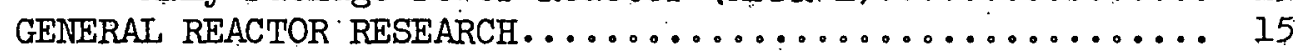

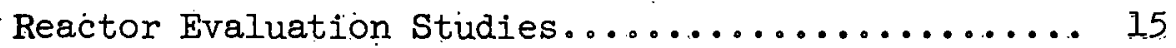

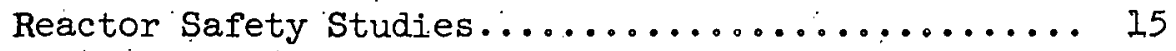

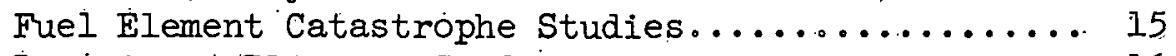

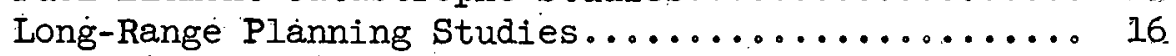

Power Reactor Fuel Reprocessing: Feed Clarification

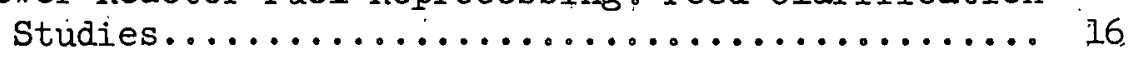

Power Reactor Fuel Reprocessing: Zirflex Process... 17

Power Reactor Fuel Reprocessing: Perflex Process... 17. 
Power Reactor Fuel Reprocessing: Sulfex Process...... 17

Power Reactor Fuel Reprocessing: Solvent Extraction

and Radiation Damage Studies............... 18

Power Reactor Fuel Reprocessing: Zircex Process..... 18

Power Reactor Fuel Reprocessing:'Darex Process...... 19

Power Reactor Fuel Reprocessing: Mechanical

Processing............................. 19

Power Reactor Fuel Reprocessing: Recovery of Uranium

and Thorium from Graphite Fuels............ 19

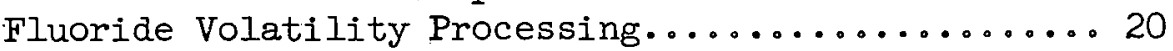

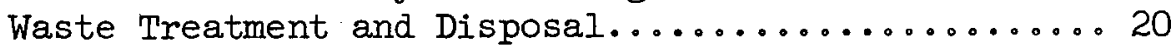

PROGRAM 5000 - PHYSICAL RESEARCH.................. 22

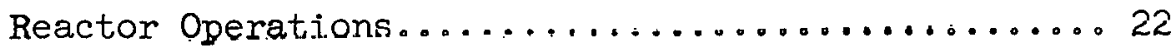

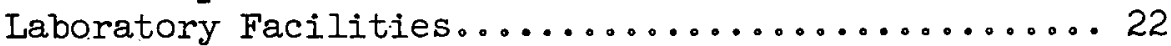

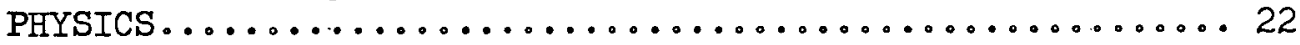

Fast-Chopper Time-of-Fll ight Spectrameter...... o. . 22

High-Voltage Experimental Program............ 22

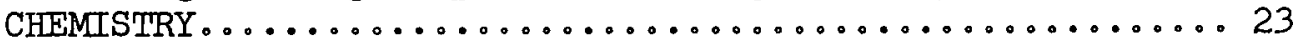

Raw Materials Research and Development......... 23

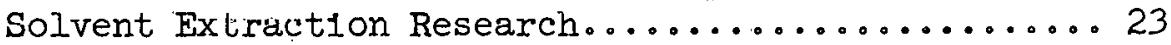

Ion Exchange Technology ..................... 24

Inorganic and Physical Chemistry: Thermochemistry

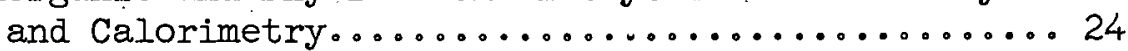

Inorganic and Physical Chemistry: Chemistry of

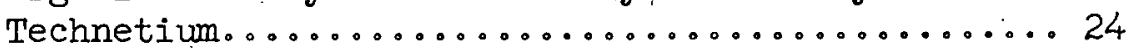

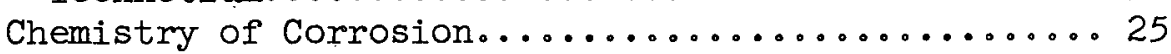

Nuclear Mcthods of Cliemical Anlalys1s............. 25

Fundamental Study of High-Temperature Chemical

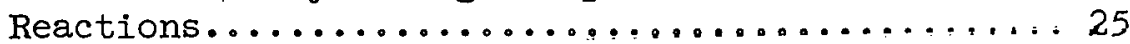

High-Temporature Aqueous pólullun Rescrtnr liemistry. 26

Chemical Separation of Isotopes................ 26

METALIURGY AND SOLID STATT PHYSICS.............. 27

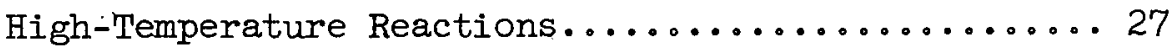

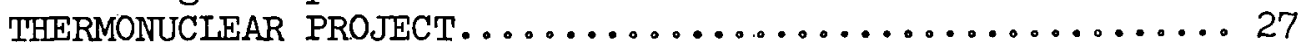

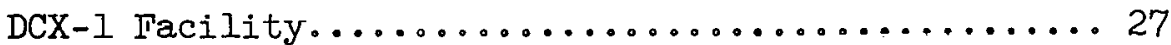

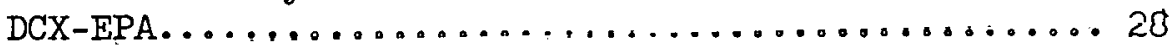

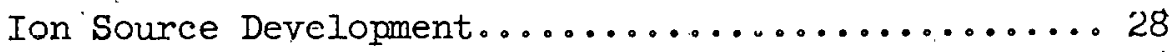

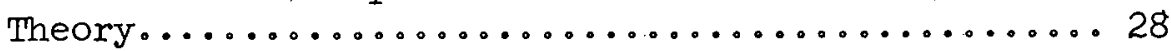

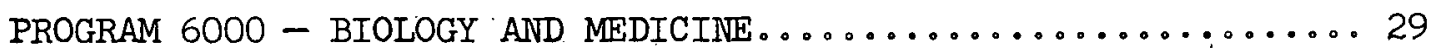

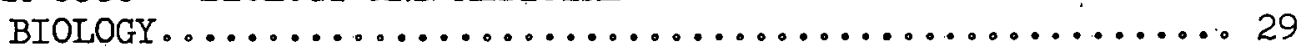

Genetic and Cytogenetic Erfects of Radiation......29

Effects of Radiation on Paramecium............. 29

Insect Cytology and Genetics................. 29

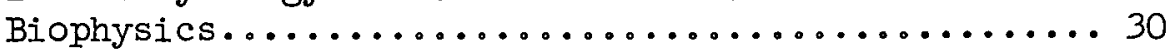

Radiation Protection: Living Cells............. 30

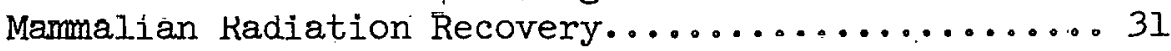

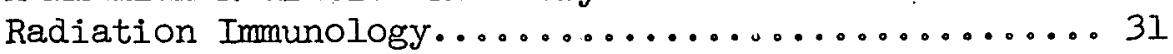

PROGRAM 8000 - WORK FOR OTHERS................... 32

International Reactor Program at ORNL.......... 32

ASEE-AEC Nuclear Engineering Institute.......... 32 
OAK RIDGE NATIONAL LABORATORY

STATUS AND PROGRESS REPORT

September 1959

This Status and Progress Report eummarizes that portion of the Laboratory's work which is unclassified. Some of the topics are included every month, but the majority are reported on a bimonthly schedule.

\section{PROGRAM 2000 - SPECIAL NUCLEAR MATERIALS}

Power Reactor Fuel Reprocessing Pilot Plant. - During August and September, 5 tons of BNL fuel and several tons of irradiated depleted uranium were processed. The plant was shut down for about 30 days after BNL fuel processing for cleanout, decontamination, and equipment repair and modification. Measured uranium and plutonium losses for the BNL fuel processing totaled 2.2 and $3.6 \%$, respectively; plant cleanout and decontamination operations accounted for $50 \%$ of the uranium and $80 \%$ of the plutonium losses. Over-all gross gamma decontamination factors across three solvent extraction cycles averaged $1.7 \times 10^{5}$ and $1.5 \times 10^{6}$, respectively, for uranium and plutonium. Both uranium and plutonium products met fission product specifications for subsequent processing。

The irradiated depleted uranium is being processed to recover plutonium containing a high percentage of $\mathrm{Pu}^{240}$. Over-all gross decontamination factors across three cycles of extraction averaged $9 \times 10^{6}$ for uranium and $4 \times 10^{6}$ for plutonium. Plutonium losses averaged 0.9\%。 (AEC Activity 2461)

\section{PROGRAM 4000 - REACTOR DEVELOPMENT}

\section{GAS-COOLED REACTOR PROGRAM}

EGCR Construction. - Management Services, Inc.., is grading the EGCR site and has started the required excavations. Approximately $120,000 \mathrm{yd}^{3}$, of an estimated total of $226,000 \mathrm{yd}^{3}$, of both rock and dirt have now been" moved. Excavations for the reactor and service buildings are being made.

The Roehl Construction Company continued work on the EGCR access:road, with progress reaching the 25\% completion level. Stripping of the roadway has. been completed. Culverts have been delivered to the site and distri-. buted to the proper locations. Fill and compaction are now in progress in the vicinity of station 0 , which is adjacent to the site. The Roehl Construction Company also continued work on the 16-in. potable water line, reashing approximately $10 \%$ completion, with about 500 ft now installed. 
Construction work on the transmission line from the EGCR site to the ORNL substation continued. Line structures have been installed, and clearing of the right of way has been completed. This work is being done by the Tennessee Valley Authority. The H. K. Ferguson Company was selected by AEC as the cost-plus-fixed-fee contractor for construction of the EGCR. (AEC Activity 4141.1)

\section{Physics of EGCR}

Results of recent detailed studies of power distribution in the EGCR with experimental loops show that:

1. There is hardly any asymmetry in the power distribution in a fuel cluster next to an empty 5-in. loop tube (near the center of the core), and the average power is the same in the next ring of fuel elements (two channels away from the loop).

2. Over-all power flattening is essentially the same as calculated during the scoping study, that is, $\left(\mathrm{P}_{\max } / \overline{\mathrm{P}}\right)_{\text {radial }} \sim 1.28$.

3. Near the large loops in positions $(12,12)$, the power is unsymmetrical in the outermost fuel channels; the variation from inner to outer edge of the cluster is about $6 \%$.

4. While the familiar upswing of the flux at the core edge next to the reflector does occur, the fuel elements do not see it; essentially all the flux variation occurs in the graphite; the power in the outer row of fuel channels is symmetrical and slightly below that in the next row of fuel elements (second rnw in from the roflector). (AEC Act1v1ty 4141.1) 
GETR Experiments. - Compressors 1 and 2 have continued to operate satisfactorlly in the GEIR loop, having accumulated about $200 \mathrm{hr}$ of operation. Considerable difficulty is still being experienced with helium leaks through gaskets and miscellaneous seals. The loop ls operating satisfactorily, however, despite the leaks. (AEC Activity 4141.I)

ORR Experiments. - Irradiation of eight capsules continues. On September 6, at the end of reactor cycle 15, the calculated burnups were as followe :

\begin{tabular}{|c|c|}
\hline Capsule & Burnup (Mwd/metric ton) \\
\hline 01 & 1227 \\
\hline 02 & 1241 \\
\hline 03 & 1389 \\
\hline 04 & 1578 \\
\hline 05 . & 1538 \\
\hline 06 & 1282 \\
\hline 07 & 992 \\
\hline 08 & 860 \\
\hline
\end{tabular}

(AEC Activity 4141.I)

Metallurgy.- Microscopic examination of several type 304 stainless steel specimens from creep tests has demonstrated the great effect which stress may have in accelerating diffusion processes. Sections are cut for microscopic examination from the gage length of the specimen and from the shoulder, which is under very low stress. Specimens 0.060 in. thick tested in $\mathrm{CO}$ at $1500^{\circ} \mathrm{F}$ were carburized to a depth of approximately 0.002 in. in the shoulder, whereas the gage length was carburized quite heavily through the entire thickness. A similar specimenttested in air at $1700^{\circ} \mathrm{F}$ was found to contain a very dense Widmanstaetten precipitate and a second-phase grainboundary network in the gage length, whereas the shoulder was void of secondphase material. In this specimen, as well as ones tested in air at $1500^{\circ} \mathrm{F}$, the gage. length exhibited intergranular oxidation throughout its thickness, but the shoulder of the specimen was uniformly oxidized to a depth of approximately 0.001 in. (AEC Activity 4141.1)

Heat Transfer Experiments. - Naphthalene mass transfer in septafoll geometries is being studied a means of estimating heat transfer. Two naphthalene mass transfer runs have been completed, using a mass transfer rod at tube position No. 4 (peripheral position) at $\mathrm{L} / \mathrm{d}_{\mathrm{e}}=17.9$ ( 1 ... in. upstream of the midcluster spacer) and at a Reynolds modulus of approximately 68,000 . The mass transfer data obtained indicate that the surface temperature asymmetries during heat transfer experimentation are not due to phenomena associated with heat transfer (e.g., variation in physical properties with temperature) but are actualiy due to flow maldistribution at the entrance 
to the test section. These data indicate the existence of a light lefthand helical flow through the tube cluster. The existence of this helical flow (which has a pitch of 3 to $5 \mathrm{ft}$ ) was confirmed by attaching fiber tufts to the inlet of the tube cluster. This swirl was found to be very unstable, and at a given flow rate it could be stopped or even reversed in direction by judiciously locating small obstructing strips in the inlet plenum chamber. (AEC Activity 4141.I)

\section{THERMAI-BREEDER REACTOR PROGRAM}

\section{Homogeneous Reactor Program}

Homogeneous Reactor Test. - Run 20 was terminated on August 30 , after the reactor had accumulated $1738 \mathrm{Mwhr}$ at power levels up to $5 \mathrm{Mw}$. It was necessary to end the mun because of the leakage of radioactive liquid through the diaphragms in the heads of the two fuel feed pumps. Both heads failed from unknown causes after only $2000 \mathrm{hr}$ of service; the expected life of these pumping units is 4000 to $8000 \mathrm{hr}$. During replacement of the pump heads, the core dump valve and fuel feed block valve were replaced also. The inside of the core vessel was examined with optical devices and photographed. The appearance of the hole, diffuser screens, and core wall was essentially unchanged from the previous viewing period which followed run 17. Core-tank thickness measurements were taken and indicated that the previously reported corrosion of 0.040 in. at the equator was incorrect; the maximum loss of wall thickness in the upper hemisphere was only 0.010 in. $4151.3)$

Startup operations preliminary to run 21 are in progress. (AEC Activity

Reactor Analysis. - Survey calculations have been made for determining the critical concentration, core-to-blanket power ratio, core-wall power density, and breeding ratio for the HRE-3 as a function nf core diameter, blanket thickness, blanket uranium concentration, and moderator composition. In the range of sizes studied, the lowest core critical concentrations occurred at moderator compositions ranging from 50 to $80 \% \mathrm{D}_{2} \mathrm{O}$. The smallest core diameter for which the core critical concentration was less than $10 \mathrm{~g} /$ liter was computed to be $2 \mathrm{ft}$ when the blanket uranium concentration was $40 \mathrm{~g}$ of $\mathrm{U}^{235}$ per $\mathrm{kg}$ of Th (1-ft-thick blankct). For a 36-in.dia core, core fuel concentrations of less than $10 \mathrm{~g} /$ liter could be obtained for a 6-in.-thick blanket containing no uranium. (AEC Activity 4151.1)

Homogeneous Reactor Instrumentation. - The transistorized electropneumatic converter developed for the Laboratory by the University of Virginia was redesigned to improve reliability and to provide packaging which is more adaptable to HRP instrument systems.

Life testing of the first of the 12 titanium bellows assemblies was completed. This unit withstood 39,420 cycles of $1 / 8 \mathrm{in}$. each in $\mathrm{UO}_{2} \mathrm{SO}_{4}$ at $285^{\circ} \mathrm{C}$ and at 2300 psig differential pressure applied externally. This bellows assembly was developed by Fulton Sylphon for a minimum life of 10,000 cycles under the conditions described above. (AEC Activity 4151.1)

Design. - The design of a manipulator for handling the miniature television camera during viewing operations inside the HRT core was completed. 
A system was designed for disposal of gases associated with corescreen removal operations.

Several design changes were prepared to improve the operational reliability of the fuel sampler and the fuel-side primary and secondary recombiners. (AEC Activity 4151.1)

Metallurgy. - In an effort to reduce the number of welds used in fabricating a.zircaloy-2 core tank and thereby increase the reliability and reduce costs, studies are being made of forming methods. The first method studied in detail was a warm power-spinning operation, which allowed the forming of flat Zircaloy-2 disks into hemispheres. Difficulties with wrin.kling and spring-back. were overcome. However, contrary to the original expectations of the fabricators, it will be necessary to spin a thicker wall than desired and machine to the final dimensions, because of variations in ellipticity and thinout. One advantage of the power-spinning process is that it results in a thick area around the pole. A finished hemisphere has been hot-pressed in the thick area to form a reverse-curvature flared opening, which provides a convenient means of attaching the vessel to a pipe. On September 10, the thickness of the HRT core vessel was surveyed. Measurements were made from inside the vessel at approximately $30^{\circ}$ intervals longitudinally and $20^{\circ}$ intervals latitudinally, using a newly designed rig and ultrasonic techniques. The thickness varied from 0.305 to 0.313 in. in the central and upper portions of the vessel. In the lower portion, values of 0.262 to $0.310 \mathrm{in}$. were obtained; however, the heavy scale present in this area caused difficulty. The original thickness varied from 0.303 to 0.317. The four vertical welds in the vessel were difficult to measure and appeared somewhat thicker than the parent plate, the thickness being in the range 0.308 to $0.330 \mathrm{in}$. One of the welds is in the location of the previous ultrasonic measurements made from the blanket access.

In past measurements, an ultrasonic resonance technique was employed, with the Vidigage being used for the thickness measurements. A recent study has revealed that the velocity of ultrasound in Zircaloy-2 varies as much as $3 \%$. Certain pecularities in the Vidigage system which arise because of the use of high-order harmonic resonances cause errors due to velocity differences to be multiplied by the harmonic number. Such an error, probably arising from the presence of the weldment, is thought to explain the single measurement of 0.278 in. made on September 25, 1958. A direct pulseecho technique was used for the new measurements. This technique measures directly the length of elapsed time between successive pulse reflections across the wall. With such a technique the maximum error can be only $4 \%$ and in practice should be much smaller. (AEC Activity 4151.1)

Laboratory Corrosion Studies. - The susceptibility of cast type 347 stainless steel to stress-corrosion cracking was examined in boiling $42 \%$ $\mathrm{MgCl}_{2}$ solution and in water containing $100 \mathrm{ppm}$ of chloride at temperatures of 200 and $300^{\circ} \mathrm{C}$. Among the variables included in the tests were stress levels from 15,000 psi to above the yield point, and machined, mechanically polished, and electropolished surface conditions. To date, no cracks have been observed under any test conditions when the metal was stressed within the elastic limit. When stressed beyond the elastic limit so as to permanently deform metal grains, cracking was observed frequently. 
A number of other cast alloys, including types 304, 3095Cb, 316, 330 SCb, and Misco C ( $29 \% \mathrm{Cr}, 10 \% \mathrm{Ni}, 0.22 \% \mathrm{C})$ stainless steels, were tested in a stressed condition in chloride-containing water at $200^{\circ} \mathrm{C}$. Four twin-strip assemblies of each alloy type were used; a portion of each strip was stressed to the point of permanent deformation. Cracks were found in all specimens of types 304, 330SCb, and Misco C stainless steel after exposure periods of $500 \mathrm{hr}$ or less. Two specimens of cast type 3095Cb stainless steel cracked in less than $100 \mathrm{hr}$, while two companion specimens survived a 1000-hr period without cracking. All four specimens of the type 316 stainless steel have passed a 1000-hr period without cracking; these tests are being continued. (AEC Activity 4151.1)

Dynamic Solution Corrosion Tests. - The second-liquid-phase temperatures for solutions initially 1.25, 2.5, 5, and 10 times as concentrated as HRT core solution during HRT run $20\left(0.03 \mathrm{~m} \mathrm{UO}_{2} \mathrm{SO}_{4}+0.018 \mathrm{~m} \mathrm{D}_{2} \mathrm{SO}_{4}+\right.$ $\left.0.015 \mathrm{~m} \mathrm{CuSO}_{4}+0.007 \mathrm{~m} \mathrm{NiSO}\right)_{1}$ ) were found to be $323,315,305$, and $307 \pm$ $5^{\circ} \mathrm{C}$, respectively, by. circulating the solutions in a titanium loop equipped with a hydroclone which separated the heavy phase. Although samples withdrawn from the hydroclone underflow pot contained heavy phase mixed with more or less light phase, it was determined that the copper- and nickel-tosulfate ratios were approximately the same in both the heavy and light phases, whereas the uranium-to-sulfate ratio was greater and the free-acidto-sulfate ratio was less in the heavy phase than in the light phase. (AEC Activity 4151.1)

In-Pile Solution Corrosion Loops. - In-pile exposure of the first ORR in-pile solution loop, 0-1-25, was completed, and the loop is being examined. The 10op was withdrawn from the reactor on september 7, 1959, after $2741 \mathrm{hr}$ of operation. The ORR operated 36,895 Mwhr during this time, mostly at the 16- to 20-Mw level. The loop was fully inserted during 30, 159 Mwhr, fully retracted during $6100 \mathrm{Mwhr}$, and partially retracted during $636 \mathrm{Mwhr}$. The estimated ratios of thermal-neutron fluxes in the fully and partially retracted positions to that in the inserted position are 0.01 and 0.60 , respectively。

The solution originally charged to the loop was $0.036 \mathrm{~m} \mathrm{UO} \mathrm{UO}_{4}, 0.024$ $\underline{m} \mathrm{H}_{2} \mathrm{SO}_{4}$, and $0.0054 \mathrm{~m} \mathrm{CuSO}_{4}$ in $\mathrm{D}_{2} \mathrm{O}$. This solution was replaced with a fresh solution of the same composition after $2078 \mathrm{hr}$ of loop operation. Temperatures of $280^{\circ} \mathrm{C}$ in the main stream and of 310,305 , or $295^{\circ} \mathrm{C}$ in the pressurizer were employed. The loop was constructed of type 347 stainless steel, and corrosion of this material, during some portions of the exposure, was greater than that encountered in prior LITR loops which employed similar solutions in $\mathrm{H}_{2} \mathrm{O}$. Complete evaluation of the corrosion results will be made after the loop examination. In general, the performance of the loop system was good, only minor difficulties being encountered.

Preliminary $\mathrm{Cs}^{\mathrm{I} 37}$ analyses of solution samples from the loop during the first $800 \mathrm{hr}$ show a fission power of about $650 \mathrm{w}$ in the loop solutinn with the reaclur at $20 \mathrm{Mw}$ and the loop in the ful.ly inserted position. This indicated loop power is about $30 \%$ greater than that found in similar solutions in LITR HB-2 loops at an LITR power of $3 \mathrm{Mw}$. No Zircaloy-2 sample activation analyses are available yet, but a flux map of the ORR facility made within a mockup core shows that the decrease in flux with increasing 
distance from the reactor lattice is greater than that in the LITR, so that the expected difference between maximum power density in the LITR and ORR facilities is greater than the difference in average power density. as indicated by cesium analyses. (AEC Activity 4151.1)

\section{Molten-Salt Reactor Program}

Chemistry: Phase Behavior. - Phase studies of the binary system $\mathrm{BeF}_{2}-\mathrm{ThF}_{4}$ were completed. A single eutectic was found at 1.5 mole $\% \operatorname{ThF}_{4}$ and $526^{\circ} \mathrm{C}$.

In the termary system $\mathrm{NaF}-\mathrm{BeF}_{2}-\mathrm{ThF}_{4}$, the peritectic reaction $\beta-4 \mathrm{NaF}$ 。 $\mathrm{ThF}_{4} \rightleftharpoons 2 \mathrm{NaF}+\beta-2 \mathrm{NaF} \cdot \mathrm{ThF}_{4}$, which occurs at $558^{\circ} \mathrm{C}$ in the binary system, is found at $543^{\circ} \mathrm{C}$; the lowered temperature is tentatively attributed to solubility of $\mathrm{BeF}_{2}$ in $4 \mathrm{NaF} \cdot \mathrm{ThF}_{4}$ and corresponds to the limit (at the composition 76 mole \% $\mathrm{NaF}^{\prime}, 11.5 \% \mathrm{BeF}_{2}, 12.5 \% \mathrm{ThF}_{4}$ ) of the liquidus in equilibrium with $4 \mathrm{NaF}^{2} \cdot \mathrm{ThF}_{4}$ 。

The effect of composition and temperature on the solubility of $\mathrm{HF}$ in $\mathrm{NaF}-\mathrm{BeF}_{2}$ was studied between 50 and 75 mole $\% \mathrm{NaF}$. A marked increase in solubility with increasing $\mathrm{NaF}$ concentration was found to occur at $67 \% \mathrm{NaF}$ and was interpreted as the effect of changing from a liquid in which the fluoride ions have $\mathrm{Be}^{++}$neighbors (tetrahedral coordination of $\mathrm{Be}^{++}$) to a liquid contajning fluoride ions like those in NaF. The heat of solution increased by a factor of 2 (to $-10 \mathrm{kcal} / \mathrm{mole}$ ) in the vicinity of the change.

The use of $\mathrm{NH}_{4} \mathrm{HF}_{2}$ in the synthesis of inorganic fluorides was explored. in connection with the conversion of $\left(\mathrm{NH}_{4}\right)_{2} \mathrm{Cr}_{2} \mathrm{O}_{7}$ and $\mathrm{CrO}_{3}$ to $\left(\mathrm{NH}_{4}\right)_{3} \mathrm{CrF} 6$ and of $\mathrm{CeO}_{2}$ to $\mathrm{CeF}_{3}$. All these reactions proceeded smoothly to give an ammon1um complex compound. (AEC Activity l.152.1)

Chemistry: Graphite Compatibility. - The best recent performance with regard to the impermeability of graphite to molten fluoride fuels and blankets was encountered with some experimental grades of fine-grained graphite tubing produced by extrusion of a blend containing coke flour and Thermatomic furnace black. These samples showed weight losses ayeraging about $0.1 \%$ after exposure to fuels at $700^{\circ} \mathrm{C}$ under 60 psig.

Although there is little reason to expect that time is an important factor in the penetration of graphite, by nonwetting liquids, such as molten fluorides, this point was checked by comparing results from 1000- and 48$\mathrm{hr}$ soaking intervals under both 60 and $2 \mathrm{psig}$. No difference with time was noted. With AGOT graphite, previously shown to be relatively permeable to fuels, the permeation occurred to about $1.5 \%$ by volume at 2 psig and $9.5 \%$ at 60 psig. Chemical analyses of concentric layers from cylindrical samples, soaked without pretreatment, showed that the permeation by a blanket fuel containing no uranium occurred uniformly except for a slight increase in the $\mathrm{Be} / \mathrm{Th}$ ratio above the nominal value toward the center. (AEC Activity 4152.1)

Metallurgy.-A series of grades of graphites with various bulk densities and various percentages of void volume were tested for penetration by the salt mixture 67 mole $\% \mathrm{LiF}, 18.5 \% \mathrm{BeF}_{2}, 14 \% \mathrm{ThF}_{4}, 0.5 \% \mathrm{UF}_{4}$ at $1300^{\circ} \mathrm{F}$ and a pressure of 150 psig. Although the percentage of the yolume of the graphite penetrated generally yaried with the density and void volume of the graphite, it was observed that graphite specifically treated to obtain 
low permeability was penetrated to a lesser extent than normal graphites with comparable densities and void volumes. GT-123, a high-density grade of extruded graphite, was found to be penetrated to only $0.13 \%$ of the bulk volume.

Several alloy systems are being investigated as potential braze materials for attaching metals to graphite. The Au-Ni-Ta system contains alloys that exhibit moderate flow on graphite at approximately $1300^{\circ} \mathrm{C}$. The application of molybdenum to graphite surfaces was accomplished both by resistance brazing and by spraying from a plasmatron. (AEC Activity 4152.1)

Corrosion Tests. - Metallographic and chemical examinations were completed on two thermal-convection loops of INOR-8 and one of Inconel; all had operated for one year. The Inconel loop, which circulated a salt mixture of the composition 53 mole $\% \mathrm{NaF}, 46 \% \mathrm{BeF}_{2}, 1.1 \% \mathrm{UF}_{4}$ at a maximum saltmetal interface temperature of $1250^{\circ} \mathrm{F}$, exhibited subsurface voids to a depth of 7 mils. (Attack in a similar system tested at $1350^{\circ} \mathrm{F}$ maximum temperature was greater by a factor of $2-1 / 2$.$) . One of the INOR-8 100ps$ circulating the same salt composition at a maximum temperature of $1350^{\circ} \mathrm{F}$ sustained only moderate pitting to $3 / 4 \mathrm{mil}$, approximately the depth of attack found in a $1250^{\circ} \mathrm{F}$ test. The other INOR-8 loop circulated blanket salt ( 58 mole $\% \mathrm{LiF}, 35 \% \mathrm{BeF}_{2}, 7 \% \mathrm{ThF}_{4}$ ) at $1350^{\circ} \mathrm{F}$; it contained intergranular subsurface voids to a depth of 2 mils. Attack of this nature was not expected in this salt and has not occurred in this temperature range with more corrosive salts; therefore the possibility of contamination of the salt is being investigated. (AEC Activity 4152.1)

Graphite Systems. - Preliminary sketches were made for a frozen-salt seal to be formed in a narrow annulus between a 5-in.-dia graphite tube and a metal tube. It is expected that the frozen-salt seal will be approximately 5 in. in length. (AEC Activity 4152.1)

In-Pile Tests. - The fuel pipe of the second MSRP in-pile loop was sectioned in preparation for the metallographic examination. The metallographic examination of the first in-pile loop was completed; the fuel and surface deposits in the pump are now being analyzed chemically.

Design of the MSRP graphite-fuel capsule test was almost completed, and fabrication and assembly work for the bench test and in-pile experiment were begun. (AEC Activity 4152.1)

Pump Development. - Testing of the helical-grooved bearing, which began last month, was concluded after $335 \mathrm{hr}$ of operation at $1200^{\circ} \mathrm{F}$ and 106 start-stops. In addition to operation at $1200 \mathrm{rpm}$ at loads up to $500 \mathrm{lb}$, it was operated at $600 \mathrm{rpm}$ with loads up to $375 \mathrm{Ib}$. The test was terminated to investigate the impending seizure which was in evilence at loads t'rom 300 to $375 \mathrm{lb}$ at $600 \mathrm{rpm}$. Small wear spots were found at each end of the bearing on the loaded side. There were corresponding wear bands encircling the journal.

Bench tests were performed on the salt-lubricated thrust-bearing tester with the thrust bearing immersed in a bath of oil. A problem of ingassing was found, and arrangements for eliminating it are under investigation. (AEC Activity 4152.1) 
Remote Maintenance Demonstration. - Eleven remote tools, adapters, and a tool rack for use with the General Milis manipulator were received.

The third and fourth sets of closed-circuit television were installed.

Modifications to the structural-steel support for the General Mills manipulator were completed.

Some remote-maintenance operations, including the removal and replacement of the pump, were started。 (AEC Activity 4152.I)

\section{Thermal-Breeder Eyaluation}

Graphite-Moderated, Gas-Cooled Breeder Reactor. - The detailed evaluation of thorium breeder reactors will proceed by examining one reactor system at a time, in sequence. The desire to examine first a solid-fuelelementreactor, and the delay entailed in preparing to handle heterogeneous reactor cell calculations, led to the selection of the graphitemoderated gas-cooled reactor as the first system for detailed examination. The following is a description of the reactor selected for parametric study.

The system selected for study consists of a cylindrical core having a diameter of 3 to $5 \mathrm{ft}$ and a length of 15 to $25 \mathrm{ft}$. The permanent graphite structure frames square fuel channels and occupies about $15 \%$ of the total volume. The fuel-element assembly consists of uranium-impregnated, unclad graphite plates about $2 \mathrm{ft}$ long, 6 to $8 \mathrm{in}$. wide, and $1 / 4$ to $3 / 4 \mathrm{in}$. thick, supported by nonfueled graphite side plates. Fuel-element structural. graphite occupies about $20 \%$ of the core volume, fuel-bearing graphite about $40 \%$, and coolant-gas passages about $25 \%$. The blanket region is nominally $2 \mathrm{ft}$ thick and consists of an extension of the core structure filled with fertile elements having plates of $\mathrm{ThO}_{2}$ ceramic. Surrounding the blanket are a graphite reflector and a boron-steel thermal shield layered with cooling channels. The pressure vessel has a diameter of 10 to $15 \mathrm{ft}$ and operates at a pressure of 750 to 2000 pei.

The core and blanket elements are charged at and discharged from both ends of the core, with countercurrent motion of elements in adjacent channels with the reactor at full power. This fueling scheme results in a steady-state core having a nearly uniform composition in respect to fuel and fissiori products.

Helium enters the core at $500^{\circ} \mathrm{F}$ and is discharged at $1500^{\circ} \mathrm{F}$. A. sufficient number of cores to produce $100 \mathrm{Mw}$ (electrical) at a gross thermodynamic efficiency of $40 \%$ are combined in a single plant.

Irradiated core and blanket elements are processed in an on-site Thorex plant. Fuel elements are stored for 90 days to allow the fission product activity to decay. They are then wet-ground in nitric acid leaching solution. The graphite is filtered off, washed, and stored in a disposal area; the filtrate is sent to the Thorex plant. Blanket elements are processed after 30 days of storage. However, additional storage of about 120 days is required for the aqueous raffinate from solvent extraction to allow $\mathrm{Pa}^{233}$ to decay. All the $\mathrm{U}^{233}$ produced is mixed with reprocessed fuel. 
The fuel is remotely reconstituted by impregnating preassembled fuel elements with solutions of uranyl nitrate and firing at $800^{\circ} \mathrm{C}$ to reduce the nitrate to the oxide. Structural graphite in the elements is protected from impregnation by a coat of wax, which is volatilized during firing.

The excess fuel, consisting of an equilibrium mixture of $\mathrm{U}^{233}$ and higher isotopes, and contaminated with $U^{232}$ and its products of decay, is accumulated for use in other reactors of the same kind. (AFC Activity 4160)

Protactinium Poison Limitation in One-Region Breeders.- An evaluation of the effect of protactinium losses in a breeder reactor in which all the thorium is intimately mixed with the fuel (as in a very large oneregion reactor) has been carried out for a reactor for which the doubling time is specified to be 25 years. For a reactor with a 25-year doubling time in wich there is no external inventory, the minimum breeding gain before subtraction of protactinium losses is about 0.10 , occurring at a specific power of about $1.9 \mathrm{Mw}$ per kilogram of fissionable uranium. If there is as much inventory external to the reactor as there is in the reactor core, the minimum breeding gain before taking protactinium losses into consideration is about 0.14 , and this occurs at a specific power of $1.5 \mathrm{Mw}$ per kilogram of fissionable uranium. It is apparent that having all the thorium intimately mixed with the fuel is a substantial handicap if a reactor with a 25-year doubling time is required. (AEC Activity 4160)

Physics - BeO-U233 Reactors. - Reactivity and conversion-ratio calculations are in progress for a series of homogeneous BeO-IR233 resctors with thorium in the core. Results indicate that, wi th optimum Be-to-U233 ratios, even quite modest specific powers lead to significant losses in conversion ratio because of neutron absorption in $\mathrm{Pa} 233$. With a Be-to$\mathrm{U}^{23} 3 \mathrm{r}^{\prime} \mathrm{t} 10$ of about 2000 and a specific power of $3600 \mathrm{kw}$ per $\mathrm{kg}$ of $\mathrm{U}^{23}$, the loss is about 0.10 in conversion ratio. Because of the large resonance integral of $\mathrm{Pa} 233$, these losses are strongly dependent on the neutron spectrum. It is likely, therefore, that even in a Th-U233 cycle in which breeding per se is not the principal objective (e.g., a power reactor with long fuel exposure), some separation of fissionable and fortile material may be desirable.

Multigroup calculations were performed to study the effects of core size, $\mathrm{U}^{233}$ and thorium concentration, blanket composition, presence of a thin buffer region between core and blanket, etc. Results to date indicate, among other things, that the achievable breeding ratio with BeO is 0.06 to 0.08 greater than with graphite moderation [mainly due to the $(n, 2 n)$ effect], and that even with a $\mathrm{BeO}$ core, a graphite blanket appears to be better than a BeO blanket; here it is simply absorption cross section, rather than moderating ratio, that matters.

The effect of the fast-neutron reactions $[(n, 2 n)$ and $(n, \alpha)]$ in BeO was computed and compared with those calculated for beryllium metal by Hafele. The results are as follows, where + and - signs indicate upper and lower limits for the $(n, 2 n)$ cross section. The quantities $\epsilon^{+}$and $\epsilon^{-}$represent upper- and lower-limit estimates of the fast effect, $\epsilon$, in each case. 


\begin{tabular}{ccccccc}
\hline Moderator & $\mathrm{P}_{\mathrm{n}, 2 \mathrm{n}}^{+}$ & $\mathrm{P}_{\mathrm{n}, 2 \mathrm{n}}^{-}$ & $\mathrm{P}_{\mathrm{n}, \alpha}^{\mathrm{Be}}$ & $\mathrm{P}_{\mathrm{n}, \alpha}^{0}$ & $\epsilon^{+}$ & $\epsilon^{-}$ \\
\hline $\mathrm{Be}$ & 0.11845 & 0.09397 & 0.04235 & & 1.076 & 1.051 \\
$\mathrm{BeO}$ & 0.07943 & 0.06034 & 0.02915 & 0.00444 & 1.046 & 1.027
\end{tabular}

NUCLEAR POWER PLANTS

(AEC Activity 4160)

Small-Size Nuclear Power Plants. - Conceptual design of the nuclear power plant was initiated by the architect-engineer, Gibbs and Hill, Inc. Preliminary drawings were reviewed by the ORNL Advisory Group, and comments were transmitted to the Oak Ridge Operations Office (AEC). Assistance was provided to OROO in the formulation of information to be included in the invitation for proposals from electrical cooperatives for participation in the program. (AEC Activity 4160)

HIGH FLUX ISOTOPE REACTOR

The preliminary design efforts have been largely concerned with nuclear optimization studies, especially efforts to maximize the thermal flux in the central island at any given reactor power but with reasonable power densities and total reactor power. If power density per unit volume is the principal practical limitation, the maximum flux is obtained in a core with uniform power distribution. The flux per megawatt can be improved a few per cent by increasing the power density near the flux trap and decreasing the power density at the outside of the core. The net result, however, is that the maximum flux significantly decreases at any given maximum power density. Design studies will be continued, aiming for uniform power distribution. The next step is to calculate reactivity, flux, and power densities as a function of fuel burnup. . 
Different methods of machine calculations give somewhat different results. A critical experiment is necessary to find which of the codes gives the most nearly correct results. A multiregion cylindrical aluminum tank, $3 \mathrm{ft}$ high and $4 \mathrm{ft}$ in diameter, is being fabricated. In the experiments the core will be filled with $\mathrm{H}_{2} \mathrm{O}$ or $\mathrm{H}_{2} \mathrm{O}-\mathrm{D}_{2} \mathrm{O}$ mixtures, the first annulus with an $\mathrm{H}_{2} \mathrm{O}-\mathrm{D}_{2} \mathrm{O}$ solution of $\mathrm{U}^{235} \mathrm{O}_{2}\left(\mathrm{NO}_{3}\right)_{2}$, and the second and third annuli with $\mathrm{D}_{2} \mathrm{O}$ and $\mathrm{H}_{2} \mathrm{O}$ reflectors, respectively. Provision is made for an $\mathrm{H}_{2} \mathrm{O}$ reflector both above and below the annular regions. A map of flux and power distribution will be made as well as a determination of the ratio of peak flux to total power.

No appreciable design efforts have been expended on portions of the project outside the core region and probably will not be until an architectengineer is selected.

The reactor core is considered to be a cylinder about 15 in. OD, 5 in. $\mathrm{ID}$, and $18 \mathrm{in}$. high, capable of operating at $100 \mathrm{Mw}$. Studies of swirl-type elements show that, although higher heat transfer and burnout coefficients are obtainable on a per unit area basis, these elements provide sufficiently less heat transfer area that a lower net heat removal per unit volume results. Three types of fuel elements are being considered.

Mark I (wedge). This type is a plate element with circumferential curved fuel plates similar to those in the MIR. The side plates are not parallel. No new developments are required before this element can be manufactured. It will be more expensive, since each plate in an element is of a different uranium content, width, and curvature. The reactor fueled with this element will not reach as high a power and flux as with Mark II or possibly Mark III.

Mark II (involute). Involute plates radiate from a central tube. Two or three concentric tubes with associated plates are required. Experimental non-fuel-bearing involute plates have been made and have been assembled into segments of a circle. To be useful, involute plates must have a variable fuel concentration across the width. Several variable fuel concentration plates have been rolled to external dimensinnal tolerance, but resulto arc not available yet on the degree of control of fuel distribution. At this time the technology of Mark II fuel elements appears accessible.

Mark III (concentric cylinder)。 If suitable spacers and spacer arrangement can be found, this element would have the higheșt performanse nf any of the current proposals. Fixperiment.s are required for dctcrmining the effect of spacers on burnout heat fluxes before a practical fuel element can be designed. This element requires the manufacturing of fuel plates of a width not previously attempted. One fuel-bearing plate was rolled which was of sufficient width and length to make one complete cylinder. No flaws were found by visual and $x$-ray inspection.

A safety factor of 2 from burnout at the hottest spot in the reactor has been established as a desirable goal. An experimental program to establish burnout heat fluxes under the specific conditions to be encountered in this reactor has been established, since available data from previous investigations do not include the ranges of the variables. The first of these programs was an investigation of vortex flow tubes for which a series of 40 twisted-tape burnout tests was conducted over the following ranges of variables: tube $I D=0.136$ to 0.402 ino; tape twist ratio $=2.08$ to 12.03 diameters/twist; $\mathrm{L} / \mathrm{D}=6.6$ to 88.2 ; tube material $=\mathrm{Al}, \mathrm{Cu}$, and " $\mathrm{A}$ " nickel; 
exit axial velocity $=14.7$ to $156 \mathrm{fps}$; exit resultant velocity $=16.6$ to $195.3 \mathrm{fps}$; inlet water temperature $=48$ to $138^{\circ} \mathrm{F}$; exit water temperature $=$ 91 to $350^{\circ} \mathrm{F}$; pressure arop $=3$ to $432 \mathrm{psi}$; burnout heat flux $=2.77 \times 10^{6}$ to $37.35 \times 10^{6} \mathrm{Btu} \cdot \mathrm{hr}^{-i} \cdot \mathrm{ft}^{-2}$.

The burnout results were best correlated by:

where

$$
\left(\Phi_{\text {bo }}\right)_{\min }=\frac{380\left(G_{r}\right)^{0.65}}{\left(D_{I}\right)^{0.2}\left(L / D_{1}\right)^{0.45}}
$$

where

$$
\begin{aligned}
& \Phi_{\mathrm{bo}}=\text { burnout heat flux, Btu. } \mathrm{hr}^{-1} \cdot \mathrm{ft}^{-2} ; \\
& \mathrm{G}_{\mathrm{r}}=\text { resultant mass velocity, } \mathrm{Ib} \cdot \mathrm{hr}^{-1} \cdot \mathrm{ft}^{-2} ; \\
& \mathrm{D}_{1}=\text { tube ID, ft; } \\
& \mathrm{L} / \mathrm{D}_{1}=\text { tube length-to-diameter ratio: }
\end{aligned}
$$

For 38 of the 40 burnout points, Eq. (1) exhibits a negative deviation of $0 \%$ and an ayerage positive deviation of $20.2 \%$.

These tests confirmed earlier indications that swirl-flow burnout heat flux is independent of degree of subcooling and of pressure, and that at constant pumping power in the same geometry, swirl flow yields burnout fluxes approximately double those for purely axial flow.

Yortex-flow surface heat transfer coefficients were also determined over broad ranges of the variables, and the results may be briefly, though approximately, summarized by stating that swirl-flow nonboiling coefficients are double those for straight flow in the same geometry at equal velocity and coolant bulk temperature.

Swirl-flow friction factors were correlated with a modified Reynolds . number, tape twist ratio, and equivalent diameter. The $j / f$ factors obtained indicate that even in nonboiling heat transfer, certain combinations of the geometric variables produce more efficient heat transmission than can be obtained with axial flow (greater amount of heat transferred for a given magnitude nf friction loss). Work on swirl-type flow for the HFIR project

\begin{tabular}{|c|c|c|c|c|}
\hline $\begin{array}{c}\text { Test } \\
\text { No. }\end{array}$ & $\begin{array}{l}\text { Flow Gap } \\
\text { (in.) }\end{array}$ & $\begin{array}{l}\text { Exit Pressure } \\
\text { (psia) }\end{array}$ & $\begin{array}{c}\text { Exit Yelocity } \\
\text { (fps) }\end{array}$ & $\begin{array}{l}\text { Burnout Flux } \\
\left(\text { Btu } \cdot h r^{-1} \cdot f t^{-2}\right)\end{array}$ \\
\hline 1 & 0.043 & . 560 & 31.8 & $3.55 \times 10^{6}$ \\
\hline 2 & 0.045 & 465 & 35.4 & $3.84 \times 10^{6}$ \\
\hline
\end{tabular}
has been terminated in order to obtain comparable information on parallel plates with narrow gaps.

Two burnout tests have been conducted with parallel plate assemblies; these are summarized below: 


$$
-14-
$$

In these tests, the plates were "A" nickel, the heated length I ft, and the flow-gap width 1-1/16. in. The observed burnout fluxes agreed within $7 \%$ with values predicted by the extended Bernath method (Preprint 110, Third National Heat Transfer Conference, August 9 - 12, 1959). A third test with nickel plates will be conducted, after which a series of aluminum test sections will be fabricated and tested. Friction factors and nonboiling heat transfer coefficients are also being spot-checked during the tests.

Another practical limitation on reactor performance is corrosion. A desirable goal of less than 2 mils penetration in 10 days has been established, since a fuel cycle of 10 days is contemplated. Ten-day dynamic corrosion tests have been completed at 200, 230, 260, and $290^{\circ} \mathrm{C}$ with types $1100,6061-T 6$, and X-8001 aluminum alloys; alloys 5154-H36 and X-2219 were included in only part of the tests. The test medium was distilled water flowing at 20 to 107 fps past the test specimens. The two alloys showing the most promising short-term corrosion behavior at temperatures up to $260^{\circ} \mathrm{C}$ were types 1100 and X-8001 aluminum; at $290^{\circ} \mathrm{C}$, type 1100 corroded severely. The table below shows the observed corrosion rates for $\mathrm{X}-8001$ aluminum based only on weight loss. Results for 1100 aluminum were very similar except at $290^{\circ} \mathrm{C}$. Preliminary metallographic examinations indicate some localized penetrations as deep as 3 mils in certain cases.

\begin{tabular}{llccc}
\hline $\begin{array}{l}\text { Velocity } \\
\begin{array}{c}\text { Range } \\
(\text { fps })\end{array}\end{array}$ & $200^{\circ} \mathrm{C}$ & $230^{\circ} \mathrm{C}$ & $260^{\circ} \mathrm{C}$ & $290^{\circ} \mathrm{C}$ \\
\hline $20-31$ & 0.7 & 0.5 & 0.2 & 1.7 \\
$31-44$ & 1.9 & 0.5 & 0.6 & 1.6 \\
$44-67$ & 1.7 & & 0.8 & 1.5 \\
$67-95$ & 2.6 & 0.8 & 3.7 & 2.8 \\
$95-107$ & 3.8 & 1.4 & 10.8 & 6.0 \\
\hline
\end{tabular}

In general, all inaterials showed velocity-dependent corrosion. The velucily effect was very pronounced at flow rates of 65 fps and above for all alloys tested. At $260^{\circ} \mathrm{C}$ the preliminary data indicated that there was no effect of cavitation on corrosion of the various alloys, since runs with overpressures of 10, 100, and 200 psi produced about the sale extert "of corrosion at all flow rates.

The prodent reactur design contemplates a hot-spot fuel plate surface temperature of $205^{\circ} \mathrm{C}$ plus an unknown temperature drop through the corrosion film. Previous investigations have shown that isothermal corrosion tests should be operated at the sum of these two temperatures. To find the correct temperature drop and to make a direct measurement of corrosion penetration, an electrically heated test section for an existing corrosion test loop has been designed and will be constructed. The test section can test aluminum channels of the same gap, water velocity, temperature, and purity as contemplated in the reactor design at heat inputs up to 1.5 times reactor design conditions. (AEC Activity 4410) 
PACKAGE REACTOR DEVETSOPMENT

Army Package Power Reactor (APPR-1). - Dimensional measurements on APPR-I'stationary and control rod fuel elements revealed that no significant changes had occurred as the result of approximately $10 \mathrm{Mw}$-years of exposure in the reactor. A slight rippling on the external plates of the stationary fuel elements was observed. Visual examination of the surfaces of various fuel plates showed no apparent evidences of cracking.

A program is in progress to determine the mechanism of boron loss during sintering of boron-stainless steel compacts, with the objective of ultimate control and prediction of such loss. Compacts of boron with the elemental metals occurring in stainless steel, or with their oxides, were sintered in high-purity argon, in a vacuum, and in wet ( $+70^{\circ} \mathrm{F}$ dew point) helium. Appreciable loss of boron was observed only in an environment which provided a source of oxygen. This suggested the following reaction sequence, with the second stage being the rate-controlling step:

$$
\begin{gathered}
4 \mathrm{~B}(\mathrm{~s})+3 \mathrm{O}_{2}(\mathrm{~g}) \rightleftharpoons 2 \mathrm{~B}_{2} \mathrm{O}_{3}(l) \\
\mathrm{B}_{2} \mathrm{O}_{3}(l) \rightleftharpoons \mathrm{B}_{2} \mathrm{O}_{3}(\mathrm{~g})
\end{gathered}
$$

(AEC Activity 4630)

\section{GENERAI REACTOR RESEARCH}

Reactor Eyaluation Studies. - The fuel value of plutonium (95\% $\mathrm{Pu}^{239}$ ) when used in various reactors (Dresden, GCR-II, SGR, Carolinas-Virginia, Yankee) has been calculated, taking into account the hardening of the neutron spectrm associated with large thermal cross sections.o The fuel value ranged from about $\$ 9$ per $\mathrm{g}$ of $\mathrm{Pu}^{239}$ in the Yankee-type reactor to about $\$ 18$ per $\mathrm{g}$ of $\mathrm{Pu}^{239}$ in the Carolinas-Virginia type of reactor. The effect of spectral hardening caused the plutonium value to be less than if this effect were not present, with the largest decrease associated with the $\mathrm{H}_{2} \mathrm{O}$-moderated reactors. (AEC Activity 4160)

Reactor Safety Studies. - The pulsed-neutron technique used to measure the neutron lifetime of the BSR-II (see ORNL-2795, p 6) was also employed to measure yalues of reactivity in the BSR-II which were too large to measure with the positive-period inhour method. These included the shitdown $\mathrm{k}$ value, the worth of the individual control rods, the worth of the reactivity insertion device, the worth of a cormer fuel element, and some shading effects of rod position. These values were verified by the inhour method where possible. The core was then disassembled, packed, and shipped (together with the auxiliary control equipment) to the SPERT-I facility for safety tests which will begin early in October. (AEC Activity 4171.1)

Fuel Elemenl Calas lrophe. Studies. - Additional experiments on the oxidation of irradiated uranium from the Hanford plutonium production gave more consistent results on the amounts of various fission products volatilized from the specimen and plated out on the attached furnace tubing. The new results are tabulated below. In. none of these experiments was any particulate 
material collected on the entrainment filter, although a slight vaporization of $\mathrm{UO}_{3}$ and a significant amount of particulate radioactivity had been observed in one previous experiment when samples were heated in air. Particles had been measured ranging from 0.3 to $1.0 \mu$.

Samples Heated at $1200^{\circ} \mathrm{C}$ in Air

\begin{tabular}{ccccccccc}
\hline $\begin{array}{c}\text { Time } \\
\text { At } \\
\begin{array}{l}\text { Temp } \\
\text { (min) }\end{array}\end{array}$ & $\begin{array}{c}\text { Amount } \\
\text { of Uranium } \\
\text { Oxidized } \\
(\%)\end{array}$ & \begin{tabular}{c} 
Gross \\
\cline { 5 - 9 }
\end{tabular} & $\begin{array}{c}\text { Gamma } \\
\text { Gamma }\end{array}$ & $\begin{array}{c}\text { Te } \\
\text { Beta }\end{array}$ & $\begin{array}{c}\text { Cs } \\
\text { Gamma }\end{array}$ & $\begin{array}{c}\text { Ru } \\
\text { Gamma }\end{array}$ & $\begin{array}{c}\text { Rare } \\
\text { Gases }\end{array}$ & $\begin{array}{c}\text { Sr } \\
\text { Beta }\end{array}$ \\
\hline 5 & 43.6 & 0.12 & 31.94 & 8.14 & 18.48 & 0.035 & 97.7 & 0.024 \\
8 & 66.2 & 0.24 & 23.16 & 12.74 & 14.53 & 0.163 & 99.2 & 0.028 \\
10 & 68 & 0.7 & 39.9 & 24.8 & 17.10 & 0.215 & 98.7 & 0.596 \\
12 & 77.5 & 3.5 & 36.4 & 23.0 & & & 99.8 & 0.9 \\
15 & 71.9 & 0.55 & 52.8 & 51.6 & 28.6 & 4.3 & 99.8 & 3.1 \\
$40 *$ & 4.1 & 0.4 & 47.0 & 0.58 & 2.03 & 0.002 & 97.7 & 0.9 \\
\hline
\end{tabular}

* Sample heated in helium atmosphere.

A single trial run, in which the uranium specimen was ignited in oxygen instead of air, resulted in the production of visible quantities of vaporized uranium oxide. Some of the particles as measured on the electron microscope were as small as $50 \AA$. The ease of vaporization of particles when uranium is burned in oxygen supports the conclusion that occasionally a sufficiently activated spot may reach vaporization temperatures when specimens are burmed in air. (AEC Activity 4171.1)

Long-Range Planning Studies. - A study was made of the energy distribution of the neutron flux in different regions of research reactors, It was found that peaking of the flux in the intermediate-energy range could be attained in. an iron region outside the fuel region; however, the absolute value of the intermediate-energy flux in the iron region was less than that in the fuel region.

Assistance is being given in connection with the thorium breeder reactor evaluation. (AEC Activity 4410)

Power Reactor Fuel Reprocessing: Feed Clarification Studies. - In comparat1ve scouting tests with a 5-ino-dia centrifuge, silica was completely. removed from solvent extraction feed solutions of dissolved Foreign Research Reactor fuel, Darex process solutions of APPR fuel, and Sulfex process solutions of type 304 stainless steel cladding, at the following feed rates and centrifugal fields: $400 \mathrm{cc} / \mathrm{min}$ a.t $800 \mathrm{~g}$ for Foreign Research Reactor feed solution, $300 \mathrm{cc} / \mathrm{min}$ at $750 \mathrm{~g}$ for Darex-APPR feed solution, and $100 \mathrm{cc} / \mathrm{min}$ at $1000 \mathrm{~g}$ for Sulfex-304 SS dejacketing solution. Thus the removal of silica from Sulfex decladding solutions appears to be more difficult (because of the higher density and viscosity of the solution). Black carbonaceous material in the sulfex solution, which is essentially impossible to filter, was removed at $100 \mathrm{cc} / \mathrm{min}$ and $350 \mathrm{~g}$. 
Spray addition of acid wash to an equal volume of cake plus supernatant at $1.3 \mathrm{~g} / \mathrm{min}$ and $30 \mathrm{psig}$ completely dislodged siliceous Darex-APPR cake from the 5-in.-dia centrifuge bowl. Successive wash additions and skimming for five cycles resulted in ayerage over-all washing efficiencies of 86 to $92 \%$ of theoretical. (AEC Activity 444I)

Power Reactor Fuel Reprocessing: Zirflex Process. - Dissolution. rates of $7 \%$ U-Zr alloy were greater than $5 \mathrm{mg} \cdot \mathrm{cm}^{-2} \cdot \mathrm{min}^{-1}$ in 4 to $6 \mathrm{M} \mathrm{NH}_{4} \mathrm{~F}$ as long as the F/Zr mole ratio in solution was greater than 7; for a mole ratio of 6 the rate was only $0.05 \mathrm{mg} / \mathrm{cm}^{2}$. At ratios below 10 the addition of $1.2 \mathrm{M}$ $\mathrm{NH}_{4} \mathrm{NO}_{3}$ to ammonium fluoride solution had little effect, but at ratios above 10, ammonium nitrate accelerated the dissolution. The highest rate measured was $42 \mathrm{mg} \cdot \mathrm{cm}^{-2} \cdot \mathrm{min}^{-1}$ in $5.4 \mathrm{M} \mathrm{NH} 4 \mathrm{~F}-1.2 \mathrm{M} \mathrm{NH} \mathrm{NHO}_{3}$ at an $\mathrm{F} / \mathrm{Zr}$ mole ratio in solution of 36.5 .

In six Zirflex cyclic corrosion tests, welded specimens of $\mathrm{Ni-0-nel}$ and type $309 \mathrm{SCb}$ stainless steel corroded at maximum rates of 0.96 and 1.02 mils/month, respectively. For heat-treated specimens of Ni-o-nel, the maximum rates in two cycles were 0.74 and $0.57 \mathrm{mil} / \mathrm{month}$ for air- and waterquenched specimens, respectively。 (AEC Activity 4441)

Power Reactor Fuel Reprocessing: Perflex Process. - Corrosion rates were obtained for Hastelloy $\mathrm{C}$ under Perflex process conditions. In five l-hr cycles in $1 \mathrm{M}$ HF- $0.06 \mathrm{M} \mathrm{H}_{2} \mathrm{O}_{2}$, the maximum over-all corrosion rates for Hastelloy $\mathrm{C}$ decreased from 87 to $57 \mathrm{mils} / \mathrm{month}$. The lower value corresppnds to 7.9 mils in 100 dissolution cycles. (AEC Activity 444.1)

Power Reactor Fuel Reprocessing: Sulfex Process: - Two $\mathrm{ThO}_{2}-\mathrm{UO}_{2}$ (Consolidated Edison) fuel pins irradiated to $200 \mathrm{Mwd} / \mathrm{ton}$ were declad in boiling $6 \mathrm{M} \mathrm{H}_{2} \mathrm{SO}_{4}$. The declad pellets remained intact during $2 \mathrm{hr}$ further exposure to the boiling decladding solution; the soluble uranium loss was 0.07 to $0.44 \%$ and the thorium loss 0.04 to $0.25 \%$. Irradiated pins as received were not passive to boiling $\mathrm{HNO}_{3}$-free $6 \mathrm{M} \mathrm{H}_{2} \mathrm{SO}_{4}$, even though the initial contact was at room temperature. As little as $0.001 \mathrm{M}^{\mathrm{HNO}} \mathrm{O}_{3}$ in boiling $6 \mathrm{M} \mathrm{H}_{2} \mathrm{SO}_{4}$ produced passivation on stainless steel jackets for periods of $1 \mathrm{hr}$ or more. Contact of the pins with $\mathrm{Ni}-\mathrm{O}-\mathrm{nel}$ did not induce passivation in the absence of $\mathrm{HNO}_{3}$. A tenfold excess of formic acid ( $u p$ to $0.02 \mathrm{M}^{2} \mathrm{HNO}_{3}$ and $0.2 \mathrm{M} \mathrm{HCOOH}$ ) did not remove the $\mathrm{HNO}_{3}$ sufficiently to break passivation in $1 \overline{\mathrm{h}} \mathrm{r}$. Elimination of $\mathrm{HNO}_{3}$ contamination from the Sulfex system required thorough, repeated water rinses, of the dissolution equipment.

Addition of ferric nitrate to the dissolvent in concentrations up to $0.5 \mathrm{M}$ increased the dissolution of high-density ( $94 \%$ of theoretical) unirradiated $95.8 \% \mathrm{ThO}_{2}-\mathrm{UO}_{2} .36$ pellets in $200 \%$ excess of boiling $13 \mathrm{M} \mathrm{HNO}_{3}-$ $0.04 \mathrm{M} \mathrm{NaF}$ to a maximum of $90 \%$ in $5 \mathrm{hr}$. Rates were lower at iron concentrations higher than $0.05 \mathrm{M}$. The amount of pellets dissolved in $1 \mathrm{hr}$ in the reagent plus $0.5 \mathrm{M} \mathrm{Fe}\left(\overline{\mathrm{N}} \mathrm{O}_{3}\right)_{3}$ plus sulfate ion decreased from $40 \%$ to $2 \%$ as the sulfate was increased from 0 to $0.3 \mathrm{M}$. Uranium losses to boiling $6 \mathrm{M} \mathrm{H}_{2} \mathrm{SO}_{4}$ from particles larger than 100 mesh were less than $0.5 \%$ in $29 \mathrm{hr}$ of digestion.

In engineering-scale tests on semicontinuous decladding of Consolidated Edison fuel, $15.5-\mathrm{kg}$ samples of type 304 stainless steel were dissolved continuously in boiling $6 \mathrm{M} \mathrm{H}_{2} \mathrm{SO}_{4}$ at a rate directly proportional 
to the dissolvent flow rate. The product concentration was maximum, $62 \mathrm{~g}$ of stainless steel per liter, at $4.7 \mathrm{M} \mathrm{H}_{2} \mathrm{SO}_{4}$; at this point the dissolution rate was $1.6 \mathrm{mg} \cdot \mathrm{cm}^{-2} \cdot \mathrm{min}^{-1}$. The mole ratio of $\mathrm{H}_{2}$ generated to stainless steel dissolved was 1.13. These data indicate a decladding time of $4 \mathrm{hr}$ for a Consolidated Edison element, assuming uniform attack.

It has been previously shown that stainless steel can be depassivated in $12 \mathrm{M} \mathrm{H}_{2} \mathrm{SO}_{4}$. However, a 5-min "depassivation" treatment in boiling $12 \mathrm{M}$ $\mathrm{H}_{2} \mathrm{SO}_{4}$ increased the corrosion rate of $\mathrm{Ni}$-o-nel from 3 to. $290 \mathrm{mils} / \mathrm{month}$. (AEC Activity 4441)

Power Reactor Fuel Reprocessing: Solvent Extraction and Radiation Damage Studies. - Laboratory experiments with an acid Interim-23 flowsheet (of possible use for Consolidated Edison fuel) with a low-acid feed gave decontamination factors from ruthenium, zirconium-niobium, and rare earths which were greater than $10^{5}$ and a uranium loss of less than $0.01 \%$. With an acid Thorex flowsheet, using 30\% tributyl phosphate in Amsco, operation was good but thorium loss was about $0.2 \%$. About $40 \%$ of the acid in the column was extracted. with the thorium.

Simple filtration of samples of recovered TBP-Amsco solvent used in high-level pilot plant runs removed as much as $99 \%$ of the gamma-active materials, the amount removed being dependent on the pore size of the filler.

A very large decrease in gross fission product decontamination factor experienced during Purex Pilot Plant operation was apparently caused by incomplete rinsing of the Turco cleaner used in previous equipment decontaminations. In laboratory experiments the addition of $1 \%$ Turco cleaner to synthetic pilot plant feed resulted in almost complete loss in decontamination from zirconium. Pilot plant solvent presumably contaminated with the cleaner was decontaminated by factors of 10 to 100 from fission products, and the agent that was complexing the zirconium was removed, by scrubbing with $0.2 \mathrm{M} \mathrm{Na}_{2} \mathrm{CO}_{3}$ and washing with $\mathrm{O} .1 \mathrm{M} \mathrm{HNO}_{3}$.

TBP-Ämsco solutions containing 0 to 100 wt $\%$ TRP were irradialed to

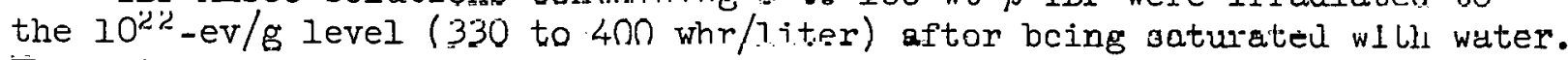
The water had essentially no effect on gas yields at any concentration or on total acid at concentrations up to 25 wt \% TBP. At higher TBP concentrations, water depressed acid formation by as much as $37 \%$.

The solubility of zirconium dibutylphosphate in aqueous uranyl nitratenitric acid solutions varied from 0.35 to $159 \mathrm{mg} / \mathrm{liter}$ as the uranium concentration increased from 0 to $490 \mathrm{~g} / \mathrm{liter}$ and the acidity from 0 to $4 \mathrm{M}$ $\mathrm{HNO}_{3}$. Corresponding zirconium solubilities in 30\% TBP-Amsco solutions equilibrated with aqueous uranyl nitrate-nitric acid were 0.33 to 3.55 g/liter. Under Purex conditions the total concentration of zirconium formed in fission of natural uranium fuel and contained in the feed solution is 40 times less than the solubility of zirconium dibutylphosphate in the extractant. (AEC Activity 4441)

Power Reactor Fuel Reprocessing: Zircex Process. - In further tests to evaluate methods for removing uranium from the vol.titile $\mathrm{ZrCl}_{4}$. etrcam, substitution of two Ni-o-nel screens $(30 \times 250 \mathrm{mcsh})$ for the glass wool packing in the $300^{\circ} \mathrm{C}$ uranium chloride desublimer caused the volatile uranium loss to increase from $<0.1 \%$ to .7 to $8 \%$. Over $99.9 \%$ of the uranium was recovered in nitric acid when glass wool packing was used. (AEC Activity 4441) 
Power Reactor Fuel Reprocessing: Darex Process. - The main emphasis on Darex process development was changed from high- to low-enriched uranium and thorium fuels as a consequence of the cancellation of the APPR-Darex pilot plant at Building 3019 and substitution of a Darex pilot plant for low-enrichment fuels at Building 2527. The processing facilities at Building 2527 will now comprise a main-line Darex facility with a Sulfex dissolver and auxiliary equipment.

In small-engineering-scale tests the ORNL reference flowsheet as applied to Yankee Atomic fuel was found to be applicable also to NS "Savannah" prototype fuel without modifications and to total dissolution of stainlesssteel-clad 5 to $8 \% \mathrm{UO}_{2}-\mathrm{ThO}_{2}$ (Consolidated Edison fuel) by adding fluoride catalyst to dissolve the mixed oxide pellets. Over-all heat transfer coefficients for chloride removal were 193 to $272 \mathrm{Btu}: \mathrm{hr}^{-1} \cdot \mathrm{ft}^{-2} \cdot\left({ }^{\circ} \mathrm{F}\right)^{-1}$.

In tests to determine $\mathrm{ThO}_{2}-\mathrm{UO}_{2} \cdot 36$ loss to $5 \mathrm{M} \mathrm{HNO}_{3}-2 \mathrm{M} \mathrm{HCl}$ Darex decladding solution, digestion of +100 -mesh oxide particles for $\overline{2} 9 \mathrm{hr}$ at boiling resulted in a uranium loss of less than $0.5 \%$.

In more refined tests to determine whether hydrogen was evolved during the Darex dissolution step, none was detected in the dissolution of $60-g$ samples of type $304 \mathrm{~L}$ stainless steel in $5 \mathrm{M} \mathrm{HNO}_{3}-2 \mathrm{M} \mathrm{HCl}$.

In continuing Darex corrosion tests, titanium showed a maximum corrosion rate of $0.23 \mathrm{mil} / \mathrm{month}$ over 13 cycles between initial and final Darex-Thorex dissolver solutions. In middle and final Thorex solutions without $\mathrm{Al}^{+++}$, the maximum rate in a $1000 \mathrm{hr}$ exposure was $0.21 \mathrm{mil} / \mathrm{month}$. in the presence of $100 \mathrm{ppm}$ of chloride (no $\mathrm{Fe}{ }^{++7}$ ), maximum rates were $8.33,0.44$, and $0.34 \mathrm{mils}$ / month in 840-hr exposures to beginning, middle, and final Thorex solutions, respectively. In beginning Thorex solutions containing 0.1 and $0.2 \mathrm{M} \mathrm{Fe}$, titanium corroded at maximum rates of 9.85 and 10.4 mils/month, respectively, in 168-hr exposures. (AEC Activity 4441)

Power Reactor Fuel. Reprocessing: Mechanical Processing. - In preliminary testing of the hydraulic SRE decladder, the tube winder and the rôlling and cutting equipment operations were satisfactory. The only malfunction was in the jackscrew drive to expel slugs from end-cropped tubes.

Plunge cutting of ferrules between the tube sheets of tubular fuel assemblies with a 1/8-in.-thick, 16-in.-dia Manhattan No. 239 abrasive-disk blade at 10,450 surface feet/min was not feasible because of blade breakage.

Ucon $150 \mathrm{cp}$ hydrolube (ethylene glycol-water solution plus additives), which appeared usable as a fire-retardant hydraulic fluid in the mechanical processing program, was tested in a radiation field to evaluate its radiation stability. At a gamma radiation dose between $10^{8}$ and $3.4 \times 10^{8} \mathrm{r}$, the material changed from a solution to a gel.

At gamma-ray exposures of $10^{10} \mathrm{r}$, Pfaudler No. 53 cover glass became separated from Pfaudler B-5 ground coat on an Inconel, Hastelloy C, or type $304 \mathrm{I}$ stainless steel base but not on a carbon steel base. (AEC Activity 4441)

Power Reactor Fuel Reprocessing: Recovery of Uranium and Thorium from Graphite Fuels. - Three spherical Pebble Bed Reactor fuel samples which had been ground to -200 mesh were leached with two portions of boiling $15.8 \mathrm{M}$ $\mathrm{HNO}_{3}$. Uranium recovery was $99.9 \%$ from the two ungraphitized admixture specimens 'but':only. $98.1 \%$ from the solution-impregnated 'ball:.

The amount of graphitized uranium-graphite fuel which disintegrated when several $37-\mathrm{g}$ samples were soaked in bromine at $25^{\circ} \mathrm{C}$ varied from nearly zero 
for a sample containing $0.7 \%$ uranium to $94 \%$ with a sample containing $9 \%$ uranium. Swelling of the fuel by the bromine did not increase" the uranium recovery by nitric acid leaching of the $9 \%$ uranium-graphite fuel over that achieved with the standard grind-leach method. However, the uranium recoveries from bromine-treated $0.7 \%$ uranium, $2 \%$ uranium, and $1.5 \%$ uranium$7.2 \%$ thorium fuels which were then leached with two portions of boiling $15.8 \mathrm{M} \mathrm{HNO}_{3}$ were 96,99 , and $94 \%$, respectively. Mechanical grinding of these fuels to $-4+8$ mesh and leaching by the same technique resulted in recoveries of only 80, 90, and 89\%, respectively. (AEC Activity 4441)

Fluoride Volatility Processing. - The fused salt-fluoride volatility process was successfully tested on a laboratory scale with $650-\mathrm{g}$ batches of fully irradiated S2W1 fuel (first."Nautilus" core) decayed 2.5 years. In two runs through the complete process, including the NaF absorptiondesorption step, the product $\mathrm{UF}_{6}$ contained essentially no activity other than that due to the $\mathrm{Th}^{231}$. daughter of $\mathrm{U}^{235}$. Ruthenium decontamination factors in the fluorination step at $500^{\circ} \mathrm{C}$ were from 110 to over $10^{3}$, in contrast to 10 or less for fused-salt fluorinations at $600^{\circ} \mathrm{C}$.

In $74.5 \mathrm{hr}$ of hydrofluorination of zirconium under proposed pilot plant flowsheet conditions, starting at 20 mole $\% \mathrm{ZrF}_{4}$ and $650^{\circ} \mathrm{C}$ and $\ldots$ ending at $45.50 \mathrm{~mole} \% \mathrm{ZrF}_{4}$ and 525 to $550^{\circ} \mathrm{C}$, the INOR- 8 vessel was corroded less than $2.5 \mathrm{mils}$. The average dissolution rate of the zirconium in six runs, with an $\mathrm{HF}$ flow rate of $4.0 \mathrm{lb} / \mathrm{hr}$, was $1.4 \mathrm{mg} \cdot \mathrm{min}^{-1} \cdot \mathrm{cm}^{-2}$, compared with $2.0 \mathrm{mg} \cdot \mathrm{min}^{-1} . \mathrm{cm}^{-2}$ for the $700^{\circ} \mathrm{C}$ flowsheet.

In low-temperature fuel dissolution studies, zirconium metal reacted vigorously with anhydrous $\mathrm{HF}$ containing $\mathrm{KF}, \mathrm{NH}_{4} \mathrm{~F}, \mathrm{NO}_{2}$, or organic materials, for example, ethanol. According to the theory of solvent systems, such. materials act as bases and increase the concentration of the flupride anion. Emphasis is being placed on the $\mathrm{NH}_{4} \mathrm{~F}-\mathrm{HF}$ system, leading to the product $\left(\mathrm{NH}_{4}\right)_{3} \mathrm{ZrF}_{7}$, which can be thermally decomposed to $\mathrm{ZrF}_{4}$. The reaction rate of 15 mole $\% \mathrm{NH}_{4} \mathrm{~F}$ in $\mathrm{HF}$ was found to be $90 \mathrm{mg} \cdot \mathrm{min}^{-1} \cdot \mathrm{cm}^{-2}$ at the reflux temperature of $60^{\circ} \mathrm{C}$.

In dissolution tests in INOR-8 equipment a black solid formed which appeared to decrease the zirconium dissolution rate and formed objectionable deposits in the system. Metallic nickel is a major constituent of the black deposit, which is believed to be the product of a chemical reduction of the $\mathrm{NiF}_{2}$ corrosion product. In a test in an all-copper system with a salt to which $\mathrm{NiF}_{2}$ had been added, typical black solids were deposited. (AEC Activity 4442)

Waste Treatment and Disposal. - Evaporation to dryness and calcination of residual solids are being studied as a means of preparing high-level solvent extraction wastes for permanent disposal. The nitrate content of calcined TBP-25 waste (aluminum nitrate base) was.found to be $0.84,0.53$, and $0.16 \%$ after $24 \mathrm{hr}$ at 600,800 , and $1000^{\circ} \mathrm{C}$, respectively. Purex waste solids were $2.7 \%$ nitrate at $400^{\circ} \mathrm{C}, 0.1$ to $0.4 \%$ at 600 to $800^{\circ} \mathrm{C}$, and $0.1 \%$ at 1000 to $1200^{\circ} \mathrm{C}$. Thorex waste solids were $5.3 \%$ nitrate at $400^{\circ} \mathrm{C}, 1.3 \%$ at $600^{\circ} \mathrm{C}$, and 0.2 to $0.5 \%$ at 800 to $1200^{\circ} \mathrm{C}$. 
In evaporation and calcination of acid wastes of various types in a stainless steel pot equipped with a glass condenser, 4 to $50 \%$ of the ruthenium was found in the condensates, as contrasted. with 0.1 to $0.2 \%$ with neutralized wastes. About 15\% of the ruthenium plated out on the calciner and condenser.

Thermogravimetric analysis of waste components indicated that both sodium and cesium are volatile as nitrates at.proposed calcination temperatures but not as sulfates.

The thermal conductivity of as-formed TBP-25 waste solids of bulk density $0.40 \mathrm{~g} / \mathrm{cc}$ is represented as a function of temperature by the empirical relation $\mathrm{k}^{\prime}\left[\mathrm{Btu} \cdot \mathrm{hr}^{-1} \cdot \mathrm{ft}^{-1} \cdot\left({ }^{\circ} \mathrm{F}\right)^{-1}\right]=0.00732+0.000244 \mathrm{~T}\left({ }^{\circ} \mathrm{F}\right)$. The thermal conductivity of Darex waste solids which were granulated after calcination to a bulk density of $1.14 \mathrm{~g} / \mathrm{cc}$ increased linearly with temperature from 0.100 at $200^{\circ} \mathrm{F}$ to 0.145 at $1500^{\circ} \mathrm{F}$.

An experimental calcination run in which concentrated simulated Darex (stainless steel nitrate) waste was fed continuously to the $8 \cdot \dot{x} 48$ in. stainless steel calcination vessel operating at $900^{\circ} \mathrm{C}$ terminated in a violent rupturing of the vessel. This resulted from the carry-over of foam into the vessel vent line, where solids were deposited. Pressure measurements from the top and bottom of the vessel indicated a uniform pressure rise from 3 to over 100 psig in about $17 \mathrm{~min}$, at which point the bottom weld failed and the vessel rocketed out of the calcination furnace. The vent system is being redesigned. (AEC Activity 4452) 


\section{$-22 .-$ \\ PROGRAM 5000 -' PHYSIQAL RESEARCH}

Reactor Operations. - The operating cycle of the ORR which ended on September 7 was the most successful to date. No unscheduled shutdown occurred during this cycle. The preliminary proposal for $30 \mathrm{Mw}$ of additional cooling capacity for the ORR has been submitted to the AEC for approval.

Approval for annealing the Graphite Reactor was received on September 11. Plans are being made to install the cross ducts this fall. If the cross ducts can be installed by spring, the annealing will be done early next summer.

Laboratory Facilities. - Work is scheduled in several of the new segmenting cells in Building 3026-D.

\section{PHYSICS}

Fast-Chopper Time-of-Flight Spectrometer. - A precise determination of the total neutron cross section of $B^{10}$ has been made from 0.018 to $0.4 \mathrm{ev}$, using boron samples highly enriched in $B^{10}$. The total cross section follows a $1 / v$ law in this energy range and has a value of $4020 \pm 30$ barns at 0.0253 ev. Total and scattering cross-section measurements have been made on platinum foils ranging in thickness from 0.001 to 0.020 in. in order to determine the parameters of the resonances up to $320 \mathrm{ev}$. Transmission measurements were also made on a sample enriched in $\mathrm{Pt}^{195}$. Of the 14 resonances assigned to $\mathrm{Pt}^{195}$ up to $320 \mathrm{ev}$, only two or possibly three have a spin of $O$, and the others have a spin of $1_{0}$. Capture cross-section measurements have been made on thin samples of Au, Pt, W, In, and Ag with a 28-in.dia liquid scintillator tank. The data are being analyzed to give the capture cross sections of the elements in the kev energy region and parameters for the resonances at Low energies. (AEC Activity 5220)

High-Voltage Experimental Program. - Since all the capture cross sections have been measured relative to indium, considerable effort has been expended in accurately determining the shape and magnitude of the indium cross section. The capture cross section of indium was measured relative to the absorption cross section of $\mathrm{U}^{235}$, using $\mathrm{Li}^{7}(p, n) \mathrm{Be}^{\prime \prime}$ neutrons from a thin lithium target in the energy range 10 to $400 \mathrm{kev}$. Neutron energies were determined from the incident proton energies, and the neutron flight times were used to distinguish capture events from background. In a second experiment, the cross section of indium as a function of energy was measured relative to the known $\mathrm{l} / \mathrm{v}$ shape of the $\mathrm{B}^{10}(n, \alpha \gamma) \mathrm{Li}^{7}$ cross section in the energy range 10 to $175 \mathrm{kev}$, using $\mathrm{Li}^{7}(\mathrm{p}, \mathrm{n}) \mathrm{Be}^{7}$ and $\mathrm{H}^{3}(\mathrm{p}, \mathrm{n}) \mathrm{He}^{3}$ neutrons from thick targets and using velocity selection to determine the neutron energies. The absolute value of the cross section was obtained by normalization to the thin-target results. In a third measurement, an indium foil was calibrated by activation with $29-\mathrm{kev}, \mathrm{Li}^{7}(\mathrm{p}, \mathrm{n}) \mathrm{Be}^{7}$ forward threshold neutrons, where the neutron flux was determined with a graphite-sphere detector. [Nuclear Instr. 1, 335 (1957)]. This calibrated foil was then activated, using 29 -kev neutrons, while measuring its gamma-ray yield with the scintillator tank. This same pair of measurements was repeated at 
$63 \mathrm{kev}$, using forward threshold neutrons from the $\mathrm{H}^{3}(\mathrm{p}, \mathrm{n}) \mathrm{He}^{3}$ reaction. Finally, from the shape of $\sigma_{a}$ of $U^{235}$ with energy and the $175-\mathrm{kev}$ value ( 1.77 barns) for $\sigma_{a}=\sigma_{f}(1+\alpha)$, the absorption cross section of $\mathrm{y}^{235}$. has been determined from 10 to $175 \mathrm{kev}$. (AEC Activity 5220)

\section{CHEMISTRY}

Raw Materials Research and Development. - The selectivity of Primene JM for thorium over rare-earth and iron contaminants was improved markedly by addition of a long-chain alcohol, to the kerosene diluent. "For example, coefficients for extraction of cerium(III) and iron(III) from sulfate solutions decreased by factors of 6 and 20, respectively, on addition of 15 vol \% tridecanol to $0.08 \mathrm{M}$ Primene JM-kerosene, whereas thorium coefficients were virtually unaffected.

In stripping thorium from Primene JM with sodium chloride solutions, effective chloride utilization ( 4 to $5 \mathrm{lb}$ of $\mathrm{NaCl}$ per $\mathrm{lb}$ of $\mathrm{ThO}_{2}$ ) was obtained by using about $300 \%$ excess chloride for stripping and recycling about $75 \%$ of the strip solution (after precipitation of thorium) to the strip circuit. A second primary amine (1-nonyldecyl), however, showed poor response to this stripping method.

Continuous tests demonstrated the feasibility of stripping uranium from tertiary amines with ammonium sulfate solutions while adjusting the $\mathrm{pH}$ to 3.5 to 4 with ammonium hydroxide. The process yields an easily filtered, high-assay, sodium-free product with low reagent costs but has the disadvantage of relatively poor separations from molybdenum. (AEC Activity 5310)

Solvent Extraction Research. - Work has continued on primary amine extraction of small concentrations of uranium and plutonium from sulfuric acid dejacketing liquor that results from decladding (Sulfex process) of stainless-steel-clad fuel. . It appears that a single-stage extraction (assuming $100 \%$ stage efficiency) with 0.3 M primary amine should recover $98 \%$ of the uranium and $95 \%$ of the plutonium from the sulfuric acid-stainlesssteel-containing dejacketing solution. This conclusion results from calculations made with distribution coefficients obtained in multistage countercurrent extraction studies (ORNL-2795). The amount of sulfate carried into the stripping product from single-stage extraction is approximately $4.5 \mathrm{~g}$ per $g$ of $U_{0}$ Previous countercurrent multistage extraction experiments have shown that $\$ 99.5 \%$ recovery of uranium and plutonium can be obtained with a sulfate concentration in the strip product of approximately $2.5 \mathrm{~g}$. per $\mathrm{g}$ of U. For recovery circuit application, single-stage extraction and stripping would be more economical and simpler to operate.

In thorium sulfate extraction by di-n-decylamine-sulfate-bisulfate in benzene, sulfuric acid is transferred back to the aqueous phase. Assuming that the extracted complex contains no bisulfate and that the presence of thorium does not alter the bisulfate content of the uncomplexed amine, measurements of such acid transfers indicated an average of slightly less than three amine sulfates per thorium in the complex, in good agreement with loading results. 
Activity coefficients were estimated for the extraction reagents tri-n-octylphosphine oxide (TOPO) and di(2-ethylhexyl)phosphoric acid (D2EHPA) (ORNL-2737) in hydrocarbon solution by using isopiestic measure-.... ments and data from the extraction of $\mathrm{Fe}\left(\mathrm{ClO}_{4}\right)_{3}$ by D2EHPA。 For $0.1 \mathrm{~m}$ D2EHPA in n-octane, $\left.\psi_{(D 2 E H P A}\right)_{2}=0.5$ and $\gamma_{\text {TOPO }} \pm 0.7$. The corresponding value for the isopiestic reference solute triphenylmethane (TPM) was $\gamma_{\text {TPM }}=0.85$, which is the first estimate available of its activity coefficient in an n-alkane solution. (AEC Activity 5310)

Ion Exchange Technology. - The apparent diffusion coefficient of uranium into $1200-\mu$ Dowex $21 \mathrm{~K}$ resin from $0.004 \mathrm{M}$ uranyl sulfate solutions was measured as $1.2 \times 10^{-7} \mathrm{~cm}^{2} / \mathrm{sec}$. This value is essentially the same as was measured with 0.0059 and $0.0029 \mathrm{M}$ uranyl sulfate solutions. The selfdiffusion coefficient of sulfate ions in uranium-loaded $1200-\mu$ Dowex $21 \mathrm{~K}$ resin was $(2.34 \pm 1.24) \times 10^{-7} \mathrm{~cm}^{2} / \mathrm{sec}$. As was expected, this value is between the true self-diffusion coefficient of sulfate ions and the uranium self-diffusion coefficient.

Equilibrium studies of Duolite S-30, a phenol-formaldehyde resinous sorbent used commercially for decolorizing sugar solutions, show that it will sorb significant quantities of alkali ions from alkaline solution and that it sorbs cesium preferentially over sodium by a factor of about 150 . The mechanism of sorption is presumably ion exchange with the weakly acid phenol group. The cation uptake from $0.1 \mathrm{M}$ NaOH was 3.8 meq per gram of dry resin, and the uptake from $0.1 \mathrm{M} \mathrm{CsOH}$ was $4.7 \mathrm{meq} / \mathrm{g}$. The distribution coefficient (weight basis) for cesium tracer in $0.01 \mathrm{M} \mathrm{NaNO}_{3}$ increased rapidly with $\mathrm{pH}$, from 750 at $\mathrm{pH} 9$ to 5400 at $\mathrm{pH} 12.2$. $^{-}$In $1.0 \mathrm{M} \mathrm{NaNO}_{3}$ the distribution coefficient increased from 45 at $\mathrm{pH} 9$ to 350 at $\mathrm{p} \overline{\mathrm{H}} 12$.

Experience with $\mathrm{Pm}^{147}$ indicated that Dowex 50 resin was still usable after receiving a beta dose of $2400 \mathrm{whr} /$ liter $(4.7 \mathrm{whr}$ per gram of dry resin).

Reactor coolant water studies, in connertion with the NS "Savannah" program, indicated an optimum demineralization flow rate of about 30 gpm per cubic foot of resin. At higher flow rates the effluent resistivity dropped due to insufficient contact time. The drop in resistivity at lower flow rates is less easily explained but is possibly due to leaching of organic ions from the resin.

A concrete block prepared with simulated reactor dcmincralizer lesin containing $10 \mathrm{mc}$ of mixed fission products showed no detectable leaching of activity by synthetic sea water in $200 \mathrm{hr}$. (AEC Activity 5310)

Inorganic and Physical Chemistry: Thermochemistry and Calorimetry。The low-temperature heat capacity of $\mathrm{K}_{2} \mathrm{ReBr}_{6}$ was measured from 10 to $300^{\circ} \mathrm{K}$. $A \cdot c o o p e r a t i v e$ type of anomaly (second-order transition) in the heat capacity was found with a maximum at approximately $15^{\circ} \mathrm{K}$. This anomaly, which is undoubtedly magnetic in origin, occurs at a considerably lower temperature than would be derived from the magnetic susceptibility. In addition, the compound exhibits an evolution of heat on warming at approximately $140^{\circ} \mathrm{K}$ and an anomalous heat capacity over the temperature range 210 to $260^{\circ} \mathrm{K}$. (AEC Activity 5330)

Inorganic and Physical Chemistry: Chemistry of Technetium. - Spectrophotometric titration with $\mathrm{Ce}\left(\mathrm{SO}_{4}\right)_{2}$ showed that reduction of $\mathrm{TcO}_{4}-$ in $\mathrm{HCl}$ 
solution with zinc produces $\mathrm{Tc}(\mathrm{III}) ; \mathrm{Tc}(\mathrm{V})$ and $\mathrm{TcCl}_{6}{ }^{--}$are produced as intermediates. At least two species of Tc(III) are obtained; one is.more stable in higher acidities and has. an absorption maximum at approximately 2650 in the ultraviolet spectrum, and the other is more stable in lower acidities and has a maximu at approximately $4200 \AA$. The maxima of both bands shift toward the red with increasing $\mathrm{HCl}$ concentration, and their helght is approximately a linear function of the acidity.. The Tc (III) is rapidly oxidized when exposed to air but is not readily. oxidized by $\mathrm{H}^{+}$and can be obtained in $8 \mathrm{M} \mathrm{HCl}$. (AEC Activity 5330)

Chemistry of Corrosion. - As part of the study of cathodic processes related to corrosion, the mechanism of reduction of oxygen on zirconium was investigated. The polarization measurements made in connection with the determination of the rate of growth of an oxide film gave good Tafel lines, and for both crystal-bar zirconium and Zircaloy-2 the cathodic process was first order with respect to the concentration of oxygen, except in certain special cases in which zero order was observed. Cathodic processes on zirconium were slow, when compared with rates on other materials. The kinetic results are consistent with a mechanism which postulates a barrier within the film. (AEC Activity 5330)

Nuclear Methods of Chemical Analysis. - The applicability of a radioactive tracer in the determination of the surface area of $\mathrm{UO}_{2}$ powder by a surface-exchange method has been demonstrated. Preliminary results indicate that the method is rapid and easy and that it can be applied with a precision of approximately 10\%. The only special requirements of the method are the availability of a suitable radioisotope tracer and radiation detection equipment. Advantages of this method are the speed and simplicity with which determinations can be made (approximately $2 \mathrm{hr}$ for four samples). (AEC Activity 5330)

Fundamental Study of High-Temperature Chemical Reactions. - Completed studies of the phase equilibria in the system CsF-ThF 4 have shown the occurrence of seven intermediate compounds. Three compounds, $3 \mathrm{CsF}^{\circ} \mathrm{ThF}_{4}, 2 \mathrm{CsF}^{\circ} \mathrm{ThF}_{4}$, and $\mathrm{CsF}^{\prime} \mathrm{ThF}_{4}$, melt congruently. Three others, $2 \mathrm{CsF} \cdot 3 \mathrm{ThF}_{4}, \mathrm{CsF} \cdot 2 \mathrm{ThF}_{4}$, and $\mathrm{CsF}^{\circ} 6 \mathrm{ThF}_{4}$, melt incongruently。 The compound $\mathrm{CsF}^{\circ} 3 \mathrm{ThF}_{4}$ is subsolidus at its composition, and $\mathrm{CsF} \cdot 2 \mathrm{ThF}_{4}$ undergoes solid-state decomposition at low temperatures. Crystal polymorphism has been observed only in the compound 2CsF: $\mathrm{ThF}_{4}$. Close resemblance of the systems $\mathrm{CsF}_{-} \mathrm{ThF}_{4}$ and $\mathrm{RbF}-\mathrm{UF}_{4}$ is observed in the liquidus profiles and in the number and characteristics of compounds in the systems.

Vapor pressure measurements on $\mathrm{LiF}_{\mathrm{UF}} \mathrm{UF}_{4}$ melts containing 10 mole \% LiF were completed. The total vapor pressure of melts of this composition is given by the equation

$$
\log \mathrm{P}(\mathrm{mm} \mathrm{Hg})=-(16550 \pm 150) / \mathrm{T}-7.046 \log \cdot \mathrm{T}+35.22 \pm 0.1 \text {, }
$$

which was obtained by a least-squares treatment of the experimental data, using an assumed $\Delta C_{p}$ of vaporization of $-14 \mathrm{cal}^{\circ} \mathrm{deg}^{-1} \cdot \mathrm{mole}^{-1}$.

X-ray diffraction studies of the condensate of the vapor phase above LiF-UFF melts (10-90 mole \%) have shown that the vapor consists of UF 4 and $\mathrm{LiF} \cdot 4 \mathrm{UF}_{4}$. The presence of compounds in the vapor phase precludes obtaining the activities of the components of the melt from vapor pressure measurements. The vapor pressure of the melt is lowered more than would be expected from 
Raoult's law, assuming $\mathrm{UF}_{4}$ to be the only volatile species. The apparent activity coefficient is 0.93. (AEC Activity 5330)

High-Temperature Aqueous Solution Reactor Chemistry. (See AEC Activity 4151.1, ORNL-2825). - The investigation of the effect of varying the proportions of nitrate and sulfate on the liquid-liquid immiscibility temperature boundaries of the system $\mathrm{UO}_{3}-\mathrm{SO}_{3}-\mathrm{N}_{2} \mathrm{O}_{5}-\mathrm{H}_{2} \mathrm{O}$ was extended to $0.16 \mathrm{~m} \mathrm{UO}_{2}{ }^{++}$solutions and to $3700^{\circ} \mathrm{C}$. . The data in the high-temperature range did not show the expected elevation of the immiscibility temperature and, in fact, showed a lowering of this temperature upon the initial substitution of nitrate for sulfate. An effort is being made to estimate the extent of loss of nitrogen oxides to the vapor phase; preliminary observations indicate that the lowering of the immiscibility temperature is only partially due to this loss.

The solubility information previously reported for the system $\mathrm{UO}_{3}-\mathrm{HNO}_{3}-$ $\mathrm{H}_{2} \mathrm{O}$ from $5 \times 10^{-4}$ to $5 \mathrm{~m} \mathrm{HNO}_{3}$ and from 135 to $300^{\circ} \mathrm{C}$ was further substantiated by additional determinations. The ultimate goal of this investigation is to obtain solubility data accurate to approximately $\pm 0.5 \%$ which can he used for theoretical evaluation of the system.

The solubility of $\mathrm{CuO}$ in $\mathrm{HNO}_{3}-\mathrm{H}_{2} \mathrm{O}$ solutions was determined at 200,270 , and $300^{\circ} \mathrm{C}$ from 0.02 to $0.6 \mathrm{~m} \cdot \mathrm{HNO}_{3}$ by direct sampling and subsequent analysis of the solution phase. For $\mathrm{O} .2 \mathrm{~m} \mathrm{HNO}_{3}$ the saturation mole ratios, $\mathrm{m}_{\mathrm{CuO}} / \mathrm{m}_{\mathrm{HNO}_{3}}$, are $0.49,0.47$, and 0.46 at 200,270 , and $300^{\circ} \mathrm{C}$, respectively, whereas for $0.02 \mathrm{~m} \mathrm{HNO}_{3}$ the corresponding saturation mole ratios are $0.44,0.41$, and 0.34.

Studies of the equilibrium $\mathrm{H}_{2} \mathrm{O}_{2}+\mathrm{UO}_{2}{ }^{++} \rightleftharpoons \mathrm{UO}_{4}+2 \mathrm{H}^{+}$in aqueous solution and the associated reactions

$$
\begin{aligned}
& \mathrm{H}_{2} \mathrm{O}_{2} \rightarrow \mathrm{H}_{2} \mathrm{O}+1 / 2 \mathrm{O}_{2}{ }^{2} \\
& \mathrm{UO}_{4} \rightarrow \mathrm{UO}_{3}+1 / 2 \mathrm{O}_{2} \\
& \mathrm{UO}_{3}+2 \mathrm{H}^{+} \rightarrow \mathrm{UO}_{2}++\mathrm{H}_{2} \mathrm{O}
\end{aligned}
$$

have qualitatively shown that the equilibrium constant $\mathrm{K}_{\mathrm{C}}$ is of the order of $10^{-2}$. The total peroxide concentration at the point of incipient precipitation of uranyl peroxide in acidic solutions of uranyl ion is not greater than $1 \times 10^{-3}$ mole/liter in $0.03 \mathrm{M} \mathrm{UO}_{2} \mathrm{SO}_{4}$ and $0.015 \mathrm{M} \mathrm{H}_{2} \mathrm{SO}_{4}$ solution at $80^{\circ} \mathrm{C}$. The rate of solution of solid $\mathrm{UO}_{4}^{-}$is rapid under conditions where solution -. can occur (i.e., before equilibrium conditions are satisfied). The total allowable peroxide concentration before precipitation of $\mathrm{UO}_{4}$ occurs increases rapidly with increasing $\mathrm{H}^{+}$concentration. (AEC Activity 5330)

Chemical Separation of Isotopes. - In order to calculate equilibrium constants for isotopic exchange reactions, investigation of the vibrational frequencies of isotopic molecules was continued. The infrared spectra of gaseous $\mathrm{N}_{2}{ }^{15} \mathrm{O}_{4}$ and $\mathrm{N}_{2}{ }^{14} \mathrm{O}_{4}$, and the Raman spectra of these species in the supercooled liquid at $-35^{\circ} \mathrm{C}$ were recorded. The 1,7 active fundamental vibrational frequencies were assigned and are presented in the table below. The data strongly support the planar. $\mathrm{N}-\mathrm{N}$ bonded structure for $\mathrm{N}_{2} \mathrm{O}_{4}$. 


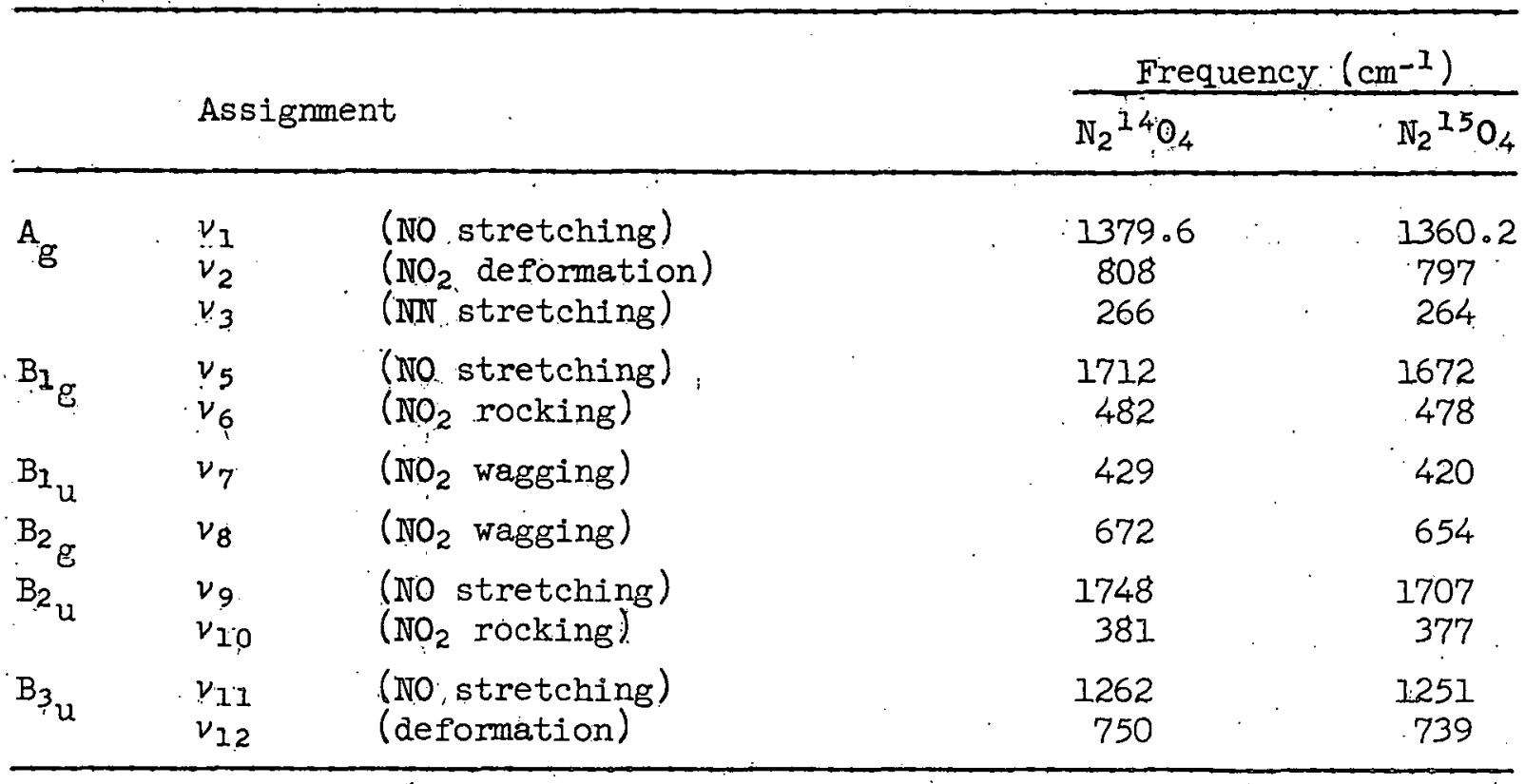

(u) infrared frequency; (g) Raman frequency. (AEC Activity 5340)

\section{METALLURGY AND SOLID STATE PHYSICS}

High-Temperature Reactions. - As a part of a study of chemical species in solutions of metals in molten salts, preliminary measurements were made of the visible absorption spectrum of solutions of bismuth in molten bismuth chloride over the temperature range 260 to $360^{\circ} \mathrm{C}$ and at concentrations up to $0.7 \mathrm{M}$ (ca.6 at. $\%$ ). Strong absorption bands were found at 560 and ca. $420 \mathrm{~m} \mu$. The effect of concentration on band intensity was such as to show that the dissolved bismuth was partitioned between two species and that the concentration of each changed as the over-all concentration of bicmuth changed. ( 1 EC Metivity 5420)

\section{THERMONUUCLEAR PROJECT}

DCX-1 Facility。 - Most of the month has been devoted to the study of an anomaly that was first observed months ago: when an obstacle is introduced endwise into the trapped $\dot{H}^{+}$plasma in $\mathrm{DCX}$, to the extent that it produces a 50\% reduction in the signal observed on a detector looking at the charge-exchanged $H^{0}$ particles flying. from the plasma, there is apparently not a concurrent reduction in the mean containment time of the plasma. One would think that the introduction of the obstacle (a carbon "paddle") would supply a new loss mechanism that would cause the plasma to live less long. The experiments have now been repeated in extenso, and the effect seems to stand. Explanations that have been suggested so far have had to be so artificial as to be almost unbelievable, and at the moment the situation is regarded as unresolved: 
With the carbon arc off, and with only the residual gas in the vacuum system to dissociate the entering $\mathrm{H}_{2}{ }^{+}$lons, mean containment times as long as $16 \mathrm{msec}$ have now been observed. Under these conditions, the plasma does not spread as it does with the arc present. The spreading mechanism is therefore associated with the arc; without it the stability of the trapped $\mathrm{H}^{+}$plasma seems to be excellent, although the densities are still low, namely, $10^{10}$ to $10^{11} \mathrm{H}^{+}$per $\mathrm{cm}^{3}$. Calculations have shown that multiple Coulomb scattering of the $\mathrm{H}^{+}$from carbon ions in the arc is entirely inadequate to explain the extent of the plasma spread with arc present, during the mean $\mathrm{H}^{+}$residence times that are observed. (AEC Activity 5540)

DCX-EPA. - Experiments have been carried out with a view to studying the relative $\mathrm{C}^{+}, \mathrm{C}^{++}$, and $\mathrm{C}^{+++}$concentrations in the carbon arc as the anode is withdrawn into the weaker-field region of the anode mirror coil and as the baffles are changed. Observations are made spectroscopically. The conclusions that have been drawn are as follows:

1. Anode baffles (which are required by the demand for differential pumping.) are bad in that they reduce the mean charge state of the carbon ions.

2. A floating baffle is worse than a grounded one.

3. A grounded baffle is the least objectionable.

4. The positions of the anode remote from the center of the machine are favorable to production of the higher charge states. (AEC Activity 5540)

Ion Source Development. - Development of the von Ardenne source continues. It has been found that the anode plate, which is customarily steel (being part of the magnetic circuit), can in fact be replaced by copper without detriment to the output, so long as the nearby zwischen electrode is steel. The result is a net improvement, inasmuch as the cooling can be improved.

A total ion beam of 150 ma has been realized at an energy of 75 to 80 kev, using an arc current of $8 \mathrm{amp}$. Assuming molecular ions, the corresponding gas efficiency is $80 \%$. Since that observation, a change in geometry indicates that $60 \mathrm{ma}$ of ion current per ampere of' arc current can be achieved, although it is presently impossible to see how far the total current can be increased, because of a limitation in the power supply currently available. (AEC Activity: 5540)

Theory。 - A complete statistical treatment of plasma particles and interacting electromagnetic radiation has led to the conclusion that the entropy of the electromagnetic field as well as the entropy of the plasma particles is a constant. The result has been used to demonstrate that only completely coherent radiation can be emitted by a plasma that obeys the Vlasov (i.e., the collisionless Boltzmann) equation.

The dissociation cross section for $\mathrm{H}_{2}{ }^{+}$ions in the carbon arc has been calculated under the Born approximation, using exact molecular wave functions (ORNL-2766). Computations are in progress, using the analog computer, but complete results are not yet at hand.

The cross sections for charge exchange of the ions $\mathrm{C}^{0}$ through $\mathrm{C}^{5}+$ have been calculated, using standard theory given by Brinkman and Kramer. The results have been distributed in the form of graphs.

The critical current required for burnout in an OGRA-like machine has been computed on the basis of theory recently derived here, using both Russian and United States cross-section values. 
The derivation of the expression for the diffusion rate of plasma across a magnetic field has been generalized; the results agree with the previous calculations made at ORNL. (AEC Activity 5540)

\section{PROGRAM 6000 - BIOLOGY AND MEDICINE}

\section{BIOLOGY}

Genetic and Cytogenetic Effects of Radiation. - Complementation and genetic mapping of ad-3 mutants of Neurospora is being continued, using mutants of spontaneous, $\mathrm{H}_{2} \mathrm{O}_{2}$, diepoxybutane, ultraviolet, and $\mathrm{x}$-ray origin. Since complementation tests on unselected samples of mutants showed that the most extensive complementation reactions are given by "leaky" mutants, several thousand ad-3 mutants are being screened for mutants of this type to expedite the complementation mapping. Present data indicate a minimum of ten cistrons and some suggestion of a nonlinear relationship. The analysis of intercrosses of complementing mutants has been started to determine the type of correlation that exists between complementation and genetic maps of this region. Such data should help provide a better understariding of gene-enzyme relationships, since it seems probable that the complementation map results from interaction in the cytoplasm between defective gene products at the ribonucleic acid or polypeptide level. (AEC Activity 6130)

Effects of Radiation on Paramecium. - Earlier work has shown that there is a sudden change in $x$-ray-induced mutation at about the midpoint of the interdivision interval in Paramecium aurelia. The amount of mutation induced by radiation is modifiable by posttreatments provided both the radiation and the posttreatment are given before the midpoint of the interval. Irradiation after the midpoint produces much less mutation than that before. Work in collaboration with T. $O$. Caspersson and his associates in Stockholm has shown by optical methods that synthesis of deoxyribonucleic acid (DNA) and other macromolecular components of the nucleus begins about midway through the interdivision interval and continues throughout the rest of the interval. It has now been. shown by quantitative autoradiography that the uptake of tritiated thymidine into.DNA likewise starts about midway through the interval and continues through the whole second half. Thus all evidence shows that the sudden change in the mutational process is associated with the onset of chromosome replication, not with its whole course. (AEC Activity 6130)

Insect Cytology and Genetics. - A method has been devised which allows for exposure of salivary gland nuclei to egg cytoplasm of varïous stages of development. Incubation of such nuclei (from Drosophila busckii larvae shortly before pupation) in cytoplasm from Drosophila melanogaster eggs before blastoderm formation ( 0 to $2 \mathrm{hr}$ ) resulted in the disappearance of the puffs $X 3$ and. IIL8 (approximate locations after the maps of Sirotina), while the puff in IIIL6 persisted. A very large puff in IIR22, a region which has never been found to puff in controls, could be seen in 56 out of 58 nuclei in which it. was possible to identify this region positively. A smaller puff was induced at IIRI7. 
Incubation in cytoplasm from eggs at the peak of blastoderm formation resulted in the disappearance of $X 3$ and IIL8 and the persisting of IIIL6. The puff at IIR22 was not induced in 16 out of 17 nuclei.

It is assumed that the puffing patterns induced correspond to a pattern of activity of loci characteristic for the respective stages in the early development of the egg. (AEC Activity 6130)

Biophysics. - The magnitudes of the radiation-induced electron spin resonances in polycrystalline glycine and in glycine molecularly adsorbed on silica gel were compared in two independent and carefully controlled experiments. The results of these experiments have corroborated previous exploratory studies indicating that the number of magnetic centers produced in the adsorbed molecule is markedly less than the number of centers produced in the pure crystalline state. This evidence supports the hypothesis that in crystalline amino acids the radiation-induced resonances do not arise entirely from lrue t'ree radicals, but rather in combination with some type of lattice defect.

A calibration of the 200 -curie $\mathrm{Cs}^{137} \mathrm{mBa} \cdot 37$ gama-ray facility has been r.nmpleted. The chronic Co 60 gamma-ray source and the chronic poloniumberyllium fast-neutron source in Building 9743-2 have both been recalibrated. Although there have been various vague remarks in and out of the literature to the effect that the neutron decay of polonium-beryllium sources does not follow the exponential radioactive decay of polonium, the $95 \%$ confidence interval for the half life for neutron decay was found to be $138.0 \pm 1.7$ days over a period of ten half lives. This agrees very well with the-last four precise determinations in the literature of the half life of $\mathrm{PO}^{210}$ as 138.4 days, with an uncertainty of no more than 0.1 day'. A systematic method for the location of lost gamma-ray or neutron sources has been developed.

Escherichia coli B, after inactivation by ultraviolet irradiation in nitrogen, shows a recovery in the presence of pure oxygen immediately after. irradiation. Detailed studies are in progress of the effect in strain $\mathrm{B} / \mathrm{r}$. It operates primarily at low survival levels (below 10\% survival). Cells inactivated to $10^{-3}$ survival are brought up to $10^{-2}$ survival by this effect. It operates with pure oxygen, but not with air. It reaches maximum level after a few minutes of bubbling with pure oxygen. The oxygen may be applied as much as 15 min after irradiation, provided the cells are kept under nitrogen bubbling in the meantime. (AEC Activity 6130)

Radiation Protection: Living Cells. - In an effort lo understand the position of the hemin błock in the porphyrin-requiring mutant of Escherichia coli $\left(\mathrm{H}_{7}\right)$, studies were carried out in a synthetic medium. During the course of these investigations it became apparent that a pigment was being formed which had not been noticeable in the complex medium on account of thc masking color of peptone. A. Targe gunntily of lie pigment was obtained and concentrated. Thu acep-i"ed pigment was partially purified by pyridine extraction. Further attempts to purify and characterize the pigment have been made and are contemplated.

Studies on the hydrogenlyase reaction in the porphyrinless mutant of E. coli showed that cells grown with hemin are not comparable with cells grown without hemin but to which the tetrapyrrole had been added in resting cell suspensions. The former had a pronounced hydrogenlyase activity, whereas the latter could not metabolize formate even in long-term experiments under conditions where adaptive formation of the enzyme has been 
studied in other strains. In contrast with these findings the addition of hemin to intact resting cells causes the imediate appearance of catalase, though this activity becomes more pronounced on prolonged incubation (AEC Activity 6230)

Mammalian Radiation Recovery. - Mouse bone marrow which had been slowfrozen in 15\% g.lycerol and.stored at various temperatures has been tested after six months of storage. Marrow stored at $-30^{\circ} \mathrm{C}$ lost its protective ability. Marrow stored at -79 and $-196^{\circ} \mathrm{C}$ retained its protective ability, although by four months the marrow stored at $-79^{\circ} \mathrm{C}$ already showed signs of deterioration.

Of 157 ( $\left.101 \times{ }^{\circ} \mathrm{C} 3 \mathrm{H}\right) \mathrm{F}_{1}$ lethally irradiated $(950 \mathrm{r}$ ) mice given $100 \mathrm{mg}$ each of isologous adult liver. on days 0,1 , and 2 after exposure, $6.4 \%$ have survived beyond 30 days. This is a small but significant survival, since irradiated controls do not survive this $x$-ray dose.

It was found by."the use of autoradiography that the radiation-protection compound $S, 2$-aminoethylisothiourea (AET) localizes primarily in the cytoplasm of mouse bone marrow cells. Some of the chemical was also found in the cell membrane and nucleus. A protective effect of AET on recovery of intestinal estera'ses and on sodium and potassium equilibria of the intestines of lethally irradiated mice has been demonstrated.

Removal of solid food following a dose of $2500 \mathrm{r}$ to the exteriorized gut was found to be a beneficial posttreatment. Treated mice lived about two days longer than controls. This technique should enable studies to be made' of the later'stages of $x$-ray damage to the gut and of the early stages of recovery.

When rat erythrocytes labeled with $\mathrm{Cr}^{5 \mathrm{I}}$ are transfused into a ratmouse chimera they have a life span somewhat shorter than that of rat red cells in the normal rat, but considerably longer than that of rat red cells in the normal mouse. However, when mouse erythrocytes are transifused into a similar chimera they usually show a normal mouse red cell life span pattern with a maximum of about 50 days. Occasional chimeras are found, however, that eliminate labeled mouse erythrocytes within a few days after transfusion. (AEC Activity 6230)

Radiation Immunology. - During the course of an investigation of the nature of antigeneantibody aggregates, a new method was devised such that the antigenic components detectable electrophoretically can be directly associated with those detectable by the serm agar diffusion method. One of the more interesting findings made with this method is that proteins having mobilities comparable with that of serm albumin are, in fact, large molecules that diffuse very slowly. Information of this nature should make possible purifications of immunochemically distinct proteins that previously appeared very difficult. (AEC Activity 6230) 
International Reactor Program at ORNL. - Twenty-five students currently enrol. ed" in the foreign programs have completed 32 weeks of school since the

$\therefore$ beginning of classes in February. "The nine Operations Supervision students have completed their classwork-at ORSORT and are now assigned to a rotating shift at one of the Laboratory's reactors 'for three months. "This course will terminate October 26,:1959. At this time, 16 Hazard Evaluation students will begin the final three months of study, which consists of the preparation by the student of a reactor hazard report covering one of four different types of reactor.

The Committee on Admissions met in August to select qualified applicants for the second session of foreign programs starting November 9, 1959. Twentysix students representing 15 foreign countries have been selected and notified of their acceptance by the Division of International Affairs, AEC. (AEC Activity 8717 )

ASEE-AEC Nuclear Engineering Institute. - Thirty participants in the 1959 ASEE-AEC Summer Institute, conducted by North Carolina State College, concluded the last two weeks of study with laboratory experiments at ORSORT. The ORSORT work consisted of seven experiments in radiochemistry and physics, tours, lectures, and movies. (AEC Activity 8736.3) 


\section{OPEN LITERATURE PUBLICATIONS}

Anderson, N. G., and R. E. Canning, "Studies on Isolated Cell Components. XII. An Ultracentrifugal Analysis of Soluble Proteins from Rat Liver, Brain, Kidney, and Testis," Exptl. Cell Research 17, 465 (1959).

Bauer, S. H., and M. Blander, "Infra Red Spectrum of Gaseous Trimethylamine," J. Mol. Spectroscopy 3, 132 (1959).

Begun, G.M., J.S. Drury, and E.F. Joseph, "Automatic Cascade for the Production of Nitrogen-15," Ind. Eng... Chem. 51, 1035 (1959).

Billington, D.S., "Radiation Effects in Crystalline Inorganic Solids," Sci. American 201,201 (1959).

Blanchard, R. L., G.W. Leddicotte, and D.W. Moeller, "Water Analysis by Neutron Activation," J. Am. Water Workș. Assoc. 51, 967 (1959).

Blander, M., "The Thermodynamics of Dilute Solutions of AgNO 3 and $\mathrm{KCl}$ in Molten $\mathrm{KNO}_{3}$ from Electromotive Force Measurements. II. A Quasi Lattice Model," J. Phys. Chem.63, 1262 (1959).

Blander, M., F. F. Blankenship, and R. F. Newton, "The Thermodynamics of Dilute Solutions of $\mathrm{AgNO}_{3}$ and $\mathrm{KCl}$ in Molten $\mathrm{KNO}_{3}$ from Electromotive Force Measurements. I. Experimental, " J. Phys. Chem. 63, 1259 (1959).

Cartiledge, G. H., "Action of the $\mathrm{xO}_{4}$ - Inhibitors, "Corrosion 15, 469 (1959).

Conger, A. D., and M. L. Randolph, "Magnetic Centers (Free Radicals) Produced in Cereal Embryos by Ionizing Radiation, "Radiation Research 11, 54 (1959).

Countryman, J. L., and E. Volkin, "Nucleic Acid Metabolism and Ribonucleic Acid Heterogeneity in Escherichia coli," J. Bacteriol. 78, 41 (1959).

Crawford, J. H., Jr., and.J.W. Cleland, "Nature of Bombardment Damage and Energy Levels in Semiconductors," J. Appl. Phys. 30, 1204. (1959).

Curtis, C. E., "Thorium Oxide in Ceramic Applications," Progr. in Nuclear Energy, Ser. V 2, 223 (1959).

Curti.s, O.L., Jr., "Radiation Effects on Recombination in Germanium;" J. Appl. Phys. 30; 1174 (1959).

Ergen, W..K., and J.A. Mohel, "Stability of a Continuous Medium Reactor," J. Nuclear Energy 10; 14 (1959).

Fabergé, A. C., "Production by Alpha Particles of Functionally Stable Broken Chromosome Ends in Maize,". Genetics 44, 279. (1959).

Gengozian, N., "Analysis of Serum from Lethally Irradiated Mice Treated with' Rat Bone Marrow," J. Immunol. 83, 173 (1959).

Gibbons, J...H., R. L. Macklin, J. B. Marion, and H. W. Schmitt, "Precision Measurement of the $\operatorname{Be}^{9}(\gamma, n)$ Cross Section, ". Phys. Rev. II. $13 I 9$ (1959). 
Gossick, B. R., (consultant), "Disordered Regions in Semiconductors Bombarded by Fast Neutrons, " J. Appl. Phys. 30, 1214 (1959).

Hollaender, A., and G. E. Stapleton, "Ionizing Radiation and the Living Cel1," Sci. American 201, 94 (1959).

Kelley, M. T., H.C.Jones, and D.J. Fisher, "Controlled-Potential and Derivative Polarograph," Anal. Chem.'31, 1475 (1959).

Kroeger, H., "Determination Mosaics from Combined Implanted Imaginal Discs in Ephestia Kuehniella Zeller," Wilhelm Roux" Arch. Entwicklungsmech. Organ. 151, 113 (1959).

Krumhansl, J.H., (consultant), "The Magnetic Susceptibility of Solids, ${ }^{n}$ J. Appl. Phys. 30, 1183 (1959).

Lindsley, .D. L., and E. Novitski, "Compound Chromosomes Involving the X and Y Chromooomce of Drooophila melanogacter, "Genetioc $\mathrm{k} / \mathrm{h}, 187$ (1959).

Makinodan, T., B.H.Friedberg, M.G. Tolbert, and N. Gengozian, "Relation of Secondary Antigen Injection to Time of Irradiation on Antibody Production in Mice," J. Immunol. 83, 184 (1959).

Miller, F. J., and P. F. Thomason, "Thermometric Titration of Acids in Presence of Hydrolyzable Cations," Anal. Chem. 31, 1498 (1959).

Miller, F. J., and P. F. Thomason, "Thermometric Titration of Uranium(IV)

$\therefore \therefore$. with Potassium Dichromate, "Anal. Chim. Acta 21, 112 (1959).

Noggle, T. S., and J. O. Stiegler, "Electron Microscope Studies on the Etching of Irradiated Germanium," J. Appl. Phys. 30, 1279 (1959).

Odell, T. T., Jr., and B. Anderson, "Production and Life Span of Platelets,"

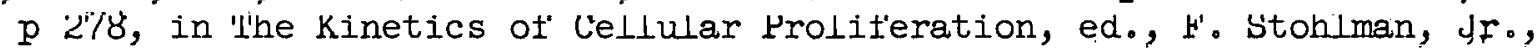
Grune and Stratton, New York, 1959.

Oen, O. S., and D. K. Holmes, "Cross Sections for Atomic Displacements in Solids by Gamma Rays," J. Appl. Phys. 30, 1289 (1959).

Owen, R. D., "Irmunogenetics," Proc. Tenth Intern. Congr. Genetics 1, 364 (1959).

Owen, R. D., "Immunology of Tissue Transplantation and Tolerance," p 31, in A Symposium on Immunity and Virus Infection, ed., V. A. Najjar, Wiley, New York, 1959.

Russell, W. I., and I. B. Russell, "Rad1ation-Induced Genet1c Dámage in Mice," Progr. in Nuclear Energy, Ser. VI 2, 179 (1959).

Schweinler, H. C., "Some Consequences of Thermal Neutron Capture in Silicon and Germanium," J. Appl. Phys. 30, 1125 (1959).

Smith, W. G., P. H. Stelson, and F.K. McGowan, "Decay of $I^{130} \rightarrow$ Xe $130 ; "$ " Phys. Rev. 114, 1345 (1959).

Sonder, E., "Magnetic and Electrical Properties of Reactor-Irradiated Silicon," J. Appl. Phys. 30, 1186.(1959). 
;-...Stoughton, R.W., and J. Halperin,. "Heavy Nuclide Cross Sections of.Par-. ticular Interest to Thermal Reactor Operation: Conventions, Measurements, and Preferred Values," Nuclear Sci. and.Eng. 6, 1.00 (1959).

Volkin, E., "Ribonucleic Acid Turnover in. Phage Infection," Proc. Intern. Congr. Biochem., 4th Congr."I, "2I2. (1959).

Watson, G. M., M. Blander, W. R. Grimes, and N. V. Smith, "Solubility of Noble Gases in Molten Fluorides. II. In the LiF-NaF-KF Eutectic Mixture," J. Phys. Chem. 63, 1164 .(1959).

Wechsler, M. S., discussion of "Precipitation Quenching and Dislocations," by. A. G. Tweet, J. Appl. Phys. 30, 1320 (1959).

Wilson, J.C., "Radiation Effects in Structural Materials at Elevated Temperatures," Progr. in Nuclear Energy, Ser. V 2, 488 (1959).

Wittels, M. C., and F.o. A. Sherrill, "Fission Fragment in Zirconia,". Phys. Rev. Letters 3, 176 (1959).

\section{FOREIGN VISITORS}

Name
Akimoto, Y.
Barloutaud, R. .
Berger, R. L.
Birien, P.
Braams, C. M.
Brinkman, H. C.
Bues, W.
Cohen, P.
Connor, J.
Davies, F.
DeJonghe, P. A. J.
Ericson, T. E. O.
Fukase, Y.
Gailledreau, C.
Glueckauf, E.
Goodfellow, H.
Goto, S.
Haven, Y. H.
de Hemptinne, X.
Herr, W.
Hoffer, W.
Iwasak1, T.

Affiliation

Mitsubish1 Metal Mining Co., Research Laboratory

C. E. N., Saclay, France

AEC, France

C. E. A., France

F. O. M. Institute

F. O. M. Institute

Technical Institute

C. E. A.; Saclay

Evans Hughes Co.

A. E. W. E.

Centre $d^{\prime} E t u d e s{ }^{8}$ Energie

Nucleaire

Massachusetts Institute of Technology

Nippon Yakin Kogyo Co.

C. E. A., Saclay

United Kingdom Atomic Energy Authority

A. E。 W。 E。

Tokyo University

Philips Research Laboratory

University of Louvain

Max Plañck Institute

Justus Liebig UnIversity

Mitsubishi Atomic Power

Industries, Inc.

\section{Citizen of}

Japan

France

France

France

The Netherlands

The Netherlands

Germany

France

Australia

Great Britain

Belgium

Sweden

Japan

France

Great Britain

Great Britain

Japan

The Netherlands

Belgium

Germany

Germany

Japan 
Name

Jeffrey, A.

Kaneshige, $K$.

Kistemaker, $\mathrm{J} \cdot$.'

Klemm, V. A.

Kronmuller, $\mathrm{H}$.

Langer, $\mathrm{W} . \mathrm{K}$.

Larsion, K. A.

Lazzerini, $\mathrm{R}$.

Lefevre, J. F. Lergouge, $\mathrm{B}$.

Low, $W$.

Luyen, P. C.

Maruffi, $M$.

Mathelot, P. J. O.

Mathot, V. D.

Mello, J. C.

Mitchell, A. R.

Nagasawa, M.

Naschi, G.

Nath, N.

Panaccione, M.

Patt1, M.

Pashley, D. W. Previti, G. Prevot, F. Puri, S. P. Santarelli, E.

Schlier, C. Schmier, H. P.

Shibata, $\mathrm{T}$ : Small, H.

Somnacal, B. Stefenson, J. $\mathrm{E}$. Swlatecki, W. J. Symons, M. C. R: Tesio, M.

Tong, K. N.
Affillation

Rolls Royce, Itd.

Atomic Energy Commission

F. O. M. Institute

Max Planck Institute

Siemans, Karlsruhe

Federal Health Board;., BerlinDahlem

A B Atomenergi

Committee for Safety and Economics of Nuclear Plants

C. E. A., France

C. E. A., France

The Hebrew University

Self

Committee for Safety and Economics of Nuclear Plants

C. E. A., France

C. E. N., Belgium

Instituto Pesquisas Radioativas

California Institute of Technology

Nagoya University

Committee for Safety and Economics of Nuclear Plants

Bartol Research Foundation

Committee for Safety and Economics of ivuclear plants

Committee for Safety and Economics ot' Nuclear Plants

Tube Investments Research Lab.

Fiat Company

French AEC

Bartol Research Foundation

Committee for Safety and Economics of Nuclear Plants

Bonn University

Federal Health Board, BerlinDahlem

Osaka Unlversily

Dow Chemical Company

Self

Kockums Shipyards

University of California

The University of Southampton

Committee for Safety and Economics of Nuclear Plants

Syracuse University
Citizen of

Great Britain

Japain

The Netherlands

Germany

Germany

Germany

Sweden

Italy

France

France

Canada

Vietnam

Italy

France

Belgium

Brazil

Great Britain

Japan

Italy

India

Italy

Italy

Great Britain

Italy

France

India

Italy

Germany

Germany

Japarn

United Kingdom

Switzerland

Sweden

United Kingdom

Great Britain

Italy;

China 
Name

Warmoltz, $\mathrm{N}$. Weals, J. W. Whelan, M. J. Yukawa, T.
Affiliation

Philips Research Laboratory A. E. W. E. Cambridge. University Kobe Steel Works, Ltd.
Citizen of:

The Netherlands Great Britain Great Britain Japan

$\begin{array}{ll} & * * * * * \\ \text { Reports issued in this series during the } \\ \text { September } 1958 & \text { ORNL-2623 } \\ \text { October 1958. } & \text { ORNL-2636 } \\ \text { November 1958 } & \text { ORNL-2645 } \\ \text { December 1958 } & \text { ORNL-2664 } \\ \text { January 1959 } & \text { ORNL-2691 } \\ \text { February 1959 } & \text { ORNL-2706 } \\ \text { March 1959 } & \text { ORNL-2721 } \\ \text { April 1959 } & \text { ORNL-2736 } \\ \text { May 1959 } & \text { ORNL-2756 } \\ \text { June } 1959 & \text { ORNL-2781 } \\ \text { July } 1959 & \text { ORNL-2795 } \\ \text { August 1959 } & \text { ORNL-2825 }\end{array}$




\section{THIS PAGE}

\section{WAS INTENTIONALLY LEFT BLANK}


OAK RIDGE NATIONAL LABORATORY

STATUS AND PROGRESS REPORT

September 1959

Distribution

U.S. Atomic Energy Commission

Oak Ridge Operations Office

1-32. Research and Development Division.

Extermal.

33. Aeroprojects, Inc.

34-36. Ames Laboratory: Iowa State College

37-39. Argonne National Laboratory

40. Atomics International (N. Am. Aviation, Inc.)

4]-42. Battelle Memorial Institute

43-45. Brookhaven National Laboratory

46. Bureau of Mines, Salt Lake City

47-48. Chicago Operations Office

49-54. Hanford Atomic Products Operation

55-56. Idatio Chemical Processing Plant

57. Kaiser Engineers

58-59. Knolls Atomic Power Laboratory

60-61. Lawrence Radiation Laboratory

62-63. Los Alamos Scientific Laboratory

64-65. National Bureau of Standards

66. National Lead Company

67: Nuclear Metals, Inc.

68. Union Carbide Corporation

69. Union Carbide Nuclear Company

70. Union Carbide Nuclear Company

71. Union Carbide Nuclear Company

72. Union Carbide Nuclear Company

W. B. Tarpley

F. H. Spedding

N. S. Hilberry

E. E. Motta

H. W. Russell

L. J. Haworth

J. B. Clemmer

O. H. Greagor

R. L. Doan

P. D. Bush

K. R. Van Tassell

D. Cooksey

N. E. Bradbury

F. L. Mohler

C. K. McArthur

A. R. Kaufmann

R. W. McNamee

C. E. Center

J. I. Gabbard

D. M. Lang

J. P. Murray

\section{Internal}

73. K. A. Allen

74. E. E. Anderson

75. E. A. Bagley

76. P. S. Baker

77. C. R. Baldock

78. L. H. Barker

79. S. E. Beall

80. E. E. Beauchamp

8.t. R. H. Beidel
82. P. R. Bell

83. D. S. Billington

84. C. A. Blake

85. R. E. Blanco

86. F. F. Blankenship

87. E. P. Blizard

88. A. L. Boch

89. E. G. Bohlmann

90. C. J. Borkowsk1 


\section{Distribution (continued)}

91. G. E. Boya

92. M. A. Bredig

93. J. C. Bresee

94. R. B. Briggs

95. R. E. Brooksbank

96. K. B. Brown

97. F. R. Bruce

98. W. D. Burch

99. T. H. J. Burnett

100. A. D. Callihan

101. A. E. Cameron

102. R. A. Charpie

103. T. E. Cole

104. C. F. Coleman

105. E. L. Compere

106. D. D. Cowen

107. J. A. Cox

108. F. L. Culler

109. J. E. Cunningham

110. J. S. Drury

111. D. E. Ferguson

112. J. I. Fowler

113. J. H. Frye

114. W. F. Gauster

115. M. W. Gerrard

116. J. H. Gillette

117. W. Y. Gissel

110. H. E. Goller

11. C. D. Çoodiman

120. A. T. Gresky

121: J. C. Griess

122. W. R. Grimes

123. P. A. Haas

124. C. S. Harrill

125. J. C. Hart

126. M。 R. Hill

127. C. J. Hochanadel

128. A. Hollaender

129. L. B. Holland.

130. R. W. Horton

131. F. T. Howard

132. A. S. Householder

133. H. H. Hubbell

13\%. G. S. Hurat

135: G. H. Jenks

136. R. W. Johnson

137. R. J. Jones

138. W. H. Jordan

139. P. R. Kasten

140. G. W. Keilholtz
141. C. P. Keim

142. M. T. Kelley

143. E. M. King

144. K. A. Kraus

145. Laboratory Shift Supervisor

146. E. Lamb (D. Phillips)

147. J. A. Lane

i48. R. E. Leuze

149. W. H. Lewis

150. T. A. Lincoln

151. S. C. Lind

152. R. B. Lindauer

153. R. S. Livingston

154. J. T. Long

155. L. O. Love

156. R. N⿴. Lyon

157. R。 J. Mackin

158. H. G. MacPherson

159. F. C. Maienschein

160. W. D. Manly

161. M。B. Marshall

162. J. A. Martin

163. H. F. McDuffie

164. J. R. MeNally

165. A. J. Miller

166. E. C. Miller

16\%. K. Z. Morgan

168. Wa I. Morgan

169. E. J. Murphy

170. M. L. Nelson

171. C. E. Normand

172. J. I. Need.

173. G. W. Parlser

174. M。 E. Ramsey

175. P. M. Reyling

176. A. W. Riikola

177. L. P. Riordan

3.78. F. A. Rกm

179. A. F。 Rupp

180. A. D. Ryon

181. H. C. Savage

182. H. W. Savage

183. A. W. Bavullantu

184. H. E. Seagren

185. E. D。 Shipley

186. A. Simon

187. 0. Sisman

188. J. R. Sites

189. M. J. Skinner 
190. A. H. Snell

191. R. W. Stoughton

192. H. Stringfield

193. E. G. Struxmess 194. W. H Sulitivan

195. C. D. Susano 196. J. A. Swartout 197. E. H. Taylor 198. C. D. Watson 199. B. S. Weaver 200. A. M. Weinberg 201. M. E. Whatley 202. J. C. White
203. C. E. Winters

204. R. E. Worsham

205. W. Zobel

206. A. Zucker

207-208. Central Research Library

209. Health Physics Library

210. ORNL - Y-12 Technical Library, Document Reference Section

211. Reactor Experimental

Engineering Library

2.12-403. Laboratory Records Department 404. Laboratory Records; ORNL R.C. 